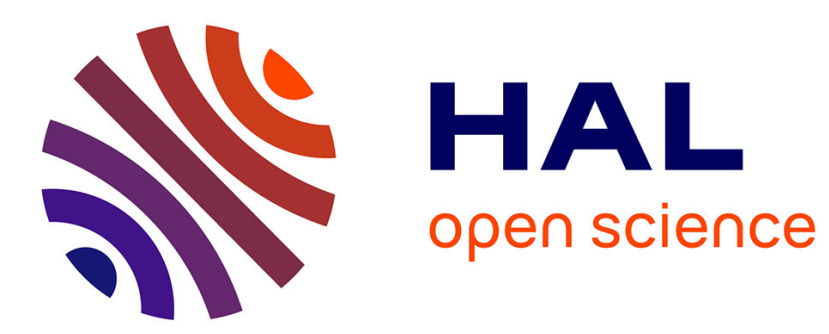

\title{
Nanoscale Evidence Unravels Microalgae Flocculation Mechanism Induced by Chitosan
}

Irem Demir, Jonas Blockx, Etienne Dague, Pascal Guiraud, Wim Thielemans, Koenraad Muylaert, Cécile Formosa-Dague

\section{> To cite this version:}

Irem Demir, Jonas Blockx, Etienne Dague, Pascal Guiraud, Wim Thielemans, et al.. Nanoscale Evidence Unravels Microalgae Flocculation Mechanism Induced by Chitosan. ACS Applied Bio Materials, 2020, 3 (12), pp.8446-8459. 10.1021/acsabm.0c00772 . hal-03025212

\author{
HAL Id: hal-03025212 \\ https://hal.laas.fr/hal-03025212
}

Submitted on 26 Nov 2020

HAL is a multi-disciplinary open access archive for the deposit and dissemination of scientific research documents, whether they are published or not. The documents may come from teaching and research institutions in France or abroad, or from public or private research centers.
L'archive ouverte pluridisciplinaire HAL, est destinée au dépôt et à la diffusion de documents scientifiques de niveau recherche, publiés ou non, émanant des établissements d'enseignement et de recherche français ou étrangers, des laboratoires publics ou privés. 


\section{Nanoscale evidences unravel microalgae flocculation mechanism} induced by chitosan

3

4 Irem Demir ${ }^{1,2 \ddagger}$, Jonas Blockx ${ }^{3,4 \ddagger}$, Etienne Dague ${ }^{2,5}$, Pascal Guiraud $^{1,5}$, Wim Thielemans ${ }^{3}$, Koenraad Muylaert ${ }^{3,4}$, and Cécile Formosa-Dague ${ }^{1,5^{*}}$

6

$7 \quad{ }^{1} \mathrm{TBI}$, Université de Toulouse, INSA, INRAE, CNRS, Toulouse, France

$8 \quad$ LAAS, Université de Toulouse, CNRS, Toulouse, France

$9{ }^{3}$ Sustainable Materials Lab, Department of Chemical Engineering, KU Leuven, Campus Kulak Kortrijk, 10 Belgium

$11{ }^{4}$ Laboratory for Aquatic Biology, KU Leuven, Campus Kulak Kortrijk, Belgium

$12{ }^{5}$ Fédération de recherche FERMAT, CNRS, Toulouse, France

¥These two authors equally contributed to the work 


\section{ABSTRACT}

In light of climate change, there is a frowing interest for sustainable energy. Microalgae are a promising resource for biofuel production, although their industrial use is limited by the lack of effective harvesting techniques. Flocculation consists in the aggregation and adhesion of cells into flocs that can be more easily removed from water than individual cells. Although it is an efficient harvesting technique, contamination is a major issue as chemical flocculants are often used. An alternative is to use natural biopolymers flocculants, such as chitosan. Chitosan is a bio-based nontoxic polymer, which has been effectively used to harvest Chlorella vulgaris cells at $\mathrm{pH}$ lower than its pKa (6.5). While the flocculation mechanism reported relied on electrostatic interactions between chitosan and the negative cell surface, no molecular evidence has yet confirmed this mechanism. In this study, we performed force spectroscopy AFM experiments to probe the interactions between $C$. vulgaris cells and chitosan at the molecular scale to decipher its flocculation mechanism. Our results showed that at $\mathrm{pH} \mathrm{6}$, chitosan interacts with $C$. vulgaris cell wall through biological interactions, rather than electrostatic interactions. These observations were confirmed by comparing the data with cationically modified cellulose nanocrystals, for which the flocculation mechanism, relying on an electrostatic patch mechanism, has already been described for $C$. vulgaris. Further AFM experiments also showed that a different mechanism was at play at higher $\mathrm{pH}$, based on chitosan precipitation. Thus this AFM-based approach highlights the complexity of chitosan-induced flocculation mechanisms for $C$. vulgaris. 
KEYWORDS: Atomic force microscopy, Force spectroscopy, Microalgae, Flocculation, Chitosan, Cellulose nano-crystals

These last two decades, the global interest for microalgae has increased, notably because of their oil production capacity that makes them an interesting alternative resource for biofuel production. ${ }^{1}$ Indeed, several studies have estimated that microalgae could produce between 40000 and $90000 \mathrm{~L}$ of biofuel per Ha, depending on the sunlight and the biomass oil content of the species considered. ${ }^{2-4}$ This represents up to 200 times more liters than soybean and 25 times more liters than oil palm. ${ }^{5}$ Among the wide variety of microalgae species, several have been considered for biofuel production such as Chlorella vulgaris. C. vulgaris is a unicellular freshwater microalgae species first discovered in 1890 by a Dutch researcher. ${ }^{6}$ This species first attracted attention in the 1950s for its nutritional value, as its protein content represents up to $55 \%$ of its dry mass ${ }^{7}$. Nowadays, $C$. vulgaris is mainly used for nutraceutical purposes; studies have shown for example that it has immune-modulating and anti-cancer properties ${ }^{8,9}$, but has also received interest for biofuel production ${ }^{4}$. Indeed, $C$. vulgaris has the capacity to accumulate important amounts of lipids under certain culture conditions, with a fatty acid profile adapted for biofuel production. ${ }^{7,10,11}$

But presently, the commercialization of microalgae-based biofuels is hindered by the lack of economically competitive harvesting techniques, as this step is generally estimated to represent 20$30 \%$ of the total microalgal biomass production cost. ${ }^{12,13}$ In the case where the harvesting step is combined with lipid extraction, as needed in biofuel production processes, this cost can increase up to $90 \%$, resulting in a negative energy balance for the production of microalgae-based biofuels at large scale. ${ }^{14-16}$ The parameters that make harvesting microalgae such a challenging task are their low concentration in water, their small cell size, their negatively charged surface, and their low density. So far, different harvesting techniques have been proposed, including centrifugation, filtration, flotation, flocculation, and electrical-based processes. A recent review compared and described the advantages and disadvantages of each of these techniques. ${ }^{13}$ Among them, flocculation stands out as it is inexpensive, making it an option for large-scale harvesting for a wide 
variety of microalgae species. ${ }^{17}$ Flocculation consists in the aggregation of cells to facilitate their separation from water by sedimentation or flotation for example. While this technique presents many advantages, a major issue in flocculation is contamination, as it often requires the use of chemical flocculants to induce flocculation, which end up in the harvested biomass, and can interfere with downstream processes or with its final application. ${ }^{18}$ In this context, an interesting alternative is to use biopolymers to induce flocculation ${ }^{19}$, the most popular in microalgae harvesting being chitosan.

Chitosan is a cationic polyelectrolyte obtained by deacetylation of chitin, an abundant natural polymer. Chitosan presents many advantages compared to traditional inorganic flocculants as it is non-toxic, biodegradable, biocompatible, and renewable. ${ }^{20,21}$ Moreover, chitosan does not contaminate the harvested biomass as chitin-like polysaccharides are naturally present in the cell wall of many microalgae species, including $C$. vulgaris, and thus harvested cells can then be directly exploited. ${ }^{22}$ Chitosan-induced flocculation has so far been used to harvest successfully both freshwater and marine microalgae species. For fresh-water species such as $C$. vulgaris, its efficiency is mostly attributed to the amino groups present in chitosan. These groups have a pKa value of about $6.5^{23}$, and thus below this $\mathrm{pH}$ these groups are mostly protonated and confer a positive charge to chitosan, which allows supposedly its electrostatic interaction with the negatively charged surface of microalgae cells. ${ }^{24}$ As a result, cells are believed to be flocculated through a charge neutralization mechanism. ${ }^{25-27}$ In the case of marine microalgae species, mixed results on chitosan efficiency have been reported. Indeed, at the high ionic strengths of marine waters, it is believed that the positives charges of chitosan are shielded, preventing further flocculation through charge neutralization. However some studies reported successful flocculation of certain marine species by chitosan ${ }^{28-31}$, which may suggest that chitosan-induced flocculation may rely on different interactions between chitosan and cells than electrostatic interactions. In this view, an interesting paper from 2011 focused on the influence of the cell wall carbohydrate composition of $C$. vulgaris on the efficiency of chitosan-induced flocculation. ${ }^{32}$ The results obtained in this study show that a higher polysaccharide 
content (including neutral sugars, uronic acids and amino sugars) in the cell wall is associated with a better efficiency of flocculation with chitosan at high $\mathrm{pH}(8.5)$, suggesting that non-electrostatic absorption of chitosan on cells may be more important than electrostatic neutralization in $C$. vulgaris. However, in all the reported cases of flocculation of $C$. vulgaris using chitosan as a flocculant, no molecular evidences has been provided, so that the mechanism(s) underlying the flocculation remains unclear.

In this study, we investigated the interactions between chitosan and C. vulgaris cells using an advanced technique: atomic force microscopy (AFM). AFM, first developed in $1986^{33}$, is a highly sensitive force machine able to record forces as small as $20 \mathrm{pN}$, making it possible to gain insights into the molecular interactions between single living cells and their environment. Our team recently used AFM to understand the flocculation mechanism involved in the cases of three different microalgae species, demonstrating the interest of using this technology to answer such questions. ${ }^{34-}$ ${ }^{36}$ Thanks to AFM force spectroscopy experiments, we show for the first time that at $\mathrm{pH} 6$ below its pKa, chitosan interacts with C. vulgaris cell wall through non-electrostatic interactions, i. e. through specific interactions between chitosan and polymers at the surface of cells that are being unfolded upon retraction. These observations were confirmed by comparing the data obtained with cationically modified cellulose nanocrystals (CNCs), for which the flocculation mechanism, relying on an electrostatic patch mechanisms, has been suggested in a previous study from our team on $C$. vulgaris. ${ }^{37}$ Further AFM experiments, including force spectroscopy but also roughness analysis, however showed that at higher $\mathrm{pH}$, the mechanism at play is different, as chitosan is not able to interact with cells at such high $\mathrm{pH}$. Thus our AFM-based approach allows in this study to highlight the complexity of chitosan-induced flocculation in the case of $C$. vulgaris, and enabled us to identify, at $\mathrm{pH}$ 6, a new flocculation mechanism based on the biological binding of chitosan with the cell wall of cells. Given the wide use of chitosan in microalgae harvesting processes, these new data provide important information to optimize microalgae-based biofuel production. 


\section{Macroscopic observations show that chitosan does not interact electrostatically with cells}

In a previous work where we evaluated the efficiency of cationically-modified CNCs to

flocculate $C$. vulgaris cells, we showed that the number of positive charges present on the CNCs was directly correlated with the flocculation efficiency. ${ }^{37}$ Indeed, CNCs bearing more positive charges allowed more efficient flocculation compared to CNCs with less positive charges. This was explained by the fact that positive CNCs interact with cells through electrostatic interactions, and thus the more positive charges present, the more interactions can occur with cells, resulting in a higher flocculation efficiency. Based on the literature, this situation should be similar for chitosan at a pH of 6 , so below the pKa value of the amine groups of chitosan. To test this hypothesis, we performed flocculation experiments using different chitosan molecules with different degrees of deacetylation (DD), thus bearing more or less positive charges. The DD of each chitosan was determined using conductometric titration and established to be of $77.5 \pm 0.8 \%, 80.5 \pm 1.4 \%$ and $85.2 \pm 0.2 \%$ (see Figure S1 and Table S1). The dynamic viscosity of the chitosan stock solutions $(5 \mathrm{~g} / \mathrm{L}$ in $0.04 \mathrm{M} \mathrm{HCl})$ was measured under different shear stress (see Table S2). Chitosan in solution acts as a nonnewtonian liquid: increasing shear stress reduces the dynamic viscosity. The results obtained for the flocculation experiments are presented in figure 1a. They show that surprisingly, the flocculation efficiency is similar for all chitosans tested, with a maximum efficiency reached for a dose of $10 \mathrm{mg} / \mathrm{L}$, thus showing that there is no influence of the DD of chitosan, and thus of its number of positive charges on the flocculation of cells. This in line with the work of Chen et al., who also showed that the DD of chitosan had indeed a limited impact on the flocculation of bentonite. ${ }^{38}$ Moreover, this study also showed that the molecular weight of chitosan had a dominant influence on the flocculation efficiency, with high molecular weights allowing to reach higher flocculation efficiencies. In our case, the MW of the chitosan that was used is of $345.2 \mathrm{kDa}$, thus high, which explains perhaps

147 the high efficiencies reached in our flocculation experiments (>95\%). To verify this observation, we compared the flocculation efficiencies with a pH of 8 where chitosan does not present positive 
charges. In this case, if the flocculation efficiency of chitosan is based on electrostatic interactions,

150 then no flocculation should be observed at this higher $\mathrm{pH}$ environment. However, the results

151 obtained, presented in Figure $1 \mathrm{~b}$, show that a maximum flocculation efficiency can be reached for the same chitosan dose both at pH 6 and 8 . While this efficiency drops at higher doses for a $\mathrm{pH}$ of 6 , it remains maximum for doses up to $80 \mathrm{mg} / \mathrm{L}$ for a $\mathrm{pH}$ of 8 . This result can be correlated to previous data obtained in our team for the marine species Nannochloropsis occulata where it was shown that chitosan was efficient even when used at higher $\mathrm{pH}$ conditions. ${ }^{31}$ It was showed that at higher $\mathrm{pH}$, the uncharged chitosan precipitates causing the flocculation of the cells through a sweeping mechanism where cells are mechanically trapped in the massive structure of the precipitate ${ }^{39}$, instead of charge neutralization as it is supposed to be the case at $\mathrm{pH} 6$. Overall the flocculation results presented here seem not to be in accordance with the literature, and comfort the idea, previously raised in 2011 in the case of $C$. vulgaris ${ }^{32}$, that the interactions between cells and chitosan

a)

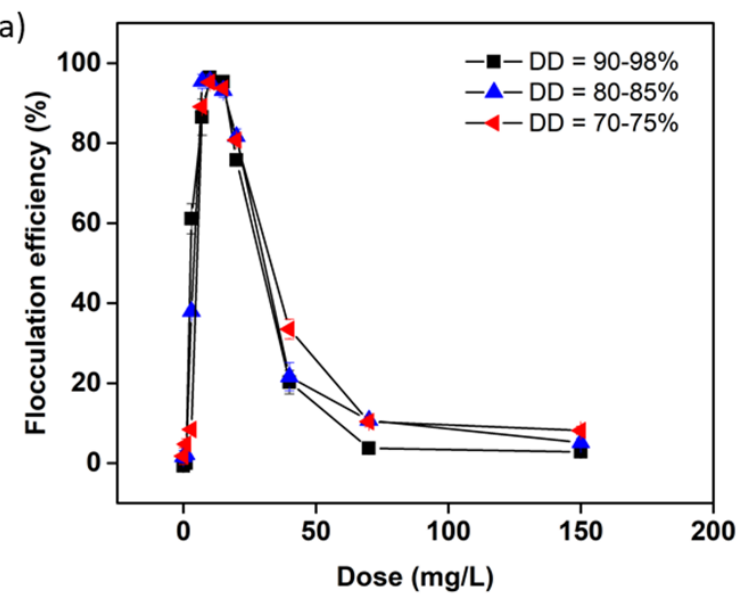

b)

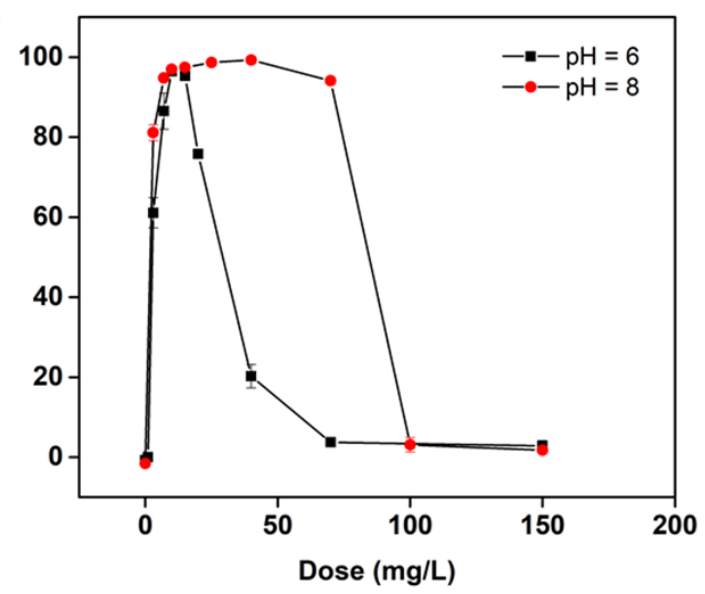

161

162

163

164

165

may not rely on electrostatic interactions.

Figure 1: Flocculation experiments of $\boldsymbol{C}$. vulgaris with chitosan. Flocculation efficiency of a) different chitosan molecules with different deacetylation degree (DD) at $\mathrm{pH} 6$ and b) chitosan molecules with $\mathrm{DD}=77.5 \pm 0.8 \%$ at $\mathrm{pH} 6$ and 8 .

To understand this phenomena further, we performed an optical microscopy assay with cells incubated with CNCs and chitosan used at concentrations for which the best flocculation efficiencies were obtained $\left(10 \mathrm{mg} / \mathrm{mL}\right.$ for chitosan and $100 \mathrm{mg} / \mathrm{L}$ for $\left.\mathrm{CNCs}^{37}\right)$. For chitosan, we chose to work 
with the chitosan with a degree of deacetylation of $77.5 \pm 0.8 \%$ ( $4.2 \mathrm{mmol}$ charges $/ \mathrm{g}$ ). Three types of CNCs were used in this study: unmodified CNCs, CNCs modified with pyridinium grafts (CNC-PYR, DS = $0.20,0.92 \mathrm{mmol}$ charges/g) and CNCs modified with methylimidazolium grafts (CNC-MIM, DS $=0.23$, $0.99 \mathrm{mmol}$ charges $/ \mathrm{g}$ ). The used CNCs were fully characterized in a previous study by the authors. ${ }^{37}$ Both CNC-PYR and CNC-MIM have quaternary ammonium groups which carry a permanent positive charge independent of $\mathrm{pH}$, unlike chitosan, for which the charge carried by its primary amines are only charged after protonation at low $\mathrm{pH}^{37,40}$ The results are presented in Figure 2 . When CNCs were used, CNCs particles can directly be observed on the images (indicated by arrows): in the case of unmodified CNCs (Figure 2a), no cells are attached to the particles, while for CNC-PYR and CNC-MIM, cells aggregated around the particles could be observed (Figure $2 b$ and c). This is then coherent with the patch mechanism already described for $C$. vulgaris in our previous work where cells interact electrostatically with CNC particles. Thus, in the case of unmodified CNCs that do not have positive charges, no interactions with cells could be observed. However for chitosan, the situation is different: at $\mathrm{pH} \mathrm{6,} \mathrm{small} \mathrm{aggregates} \mathrm{of} \mathrm{cells} \mathrm{were} \mathrm{observed,} \mathrm{with} \mathrm{smaller} \mathrm{size} \mathrm{than} \mathrm{the} \mathrm{CNC} \mathrm{aggregates} \mathrm{(Figure}$ 2e), suggesting that chitosan does interact with cells, but that perhaps the nature of the bond is different, not as strong as in the case of CNCs. At pH 8, cells do not seem to be aggregated (Figure 2f). If we follow the hypothesis formulated in our previous work on N. occulata ${ }^{31}$, then this results could be explained by the fact that at higher $\mathrm{pH}$, the flocculation mechanism is based on sweeping, and thus there are no direct interactions between chitosan and cells. This is also in line with what was already demonstrated on another microalgae species, Dunaliella salina; when sweeping mechanism is involved, there are no interactions between the flocculant and the cells. ${ }^{35}$ Thus, at this stage, our macroscopic analysis seems to show that in contrast to the literature, chitosan-induced flocculation in C. vulgaris may not rely on electrostatic interactions, even at $\mathrm{pH} 6$ where chitosan is positively charged. However, what is then the mechanism involved? 

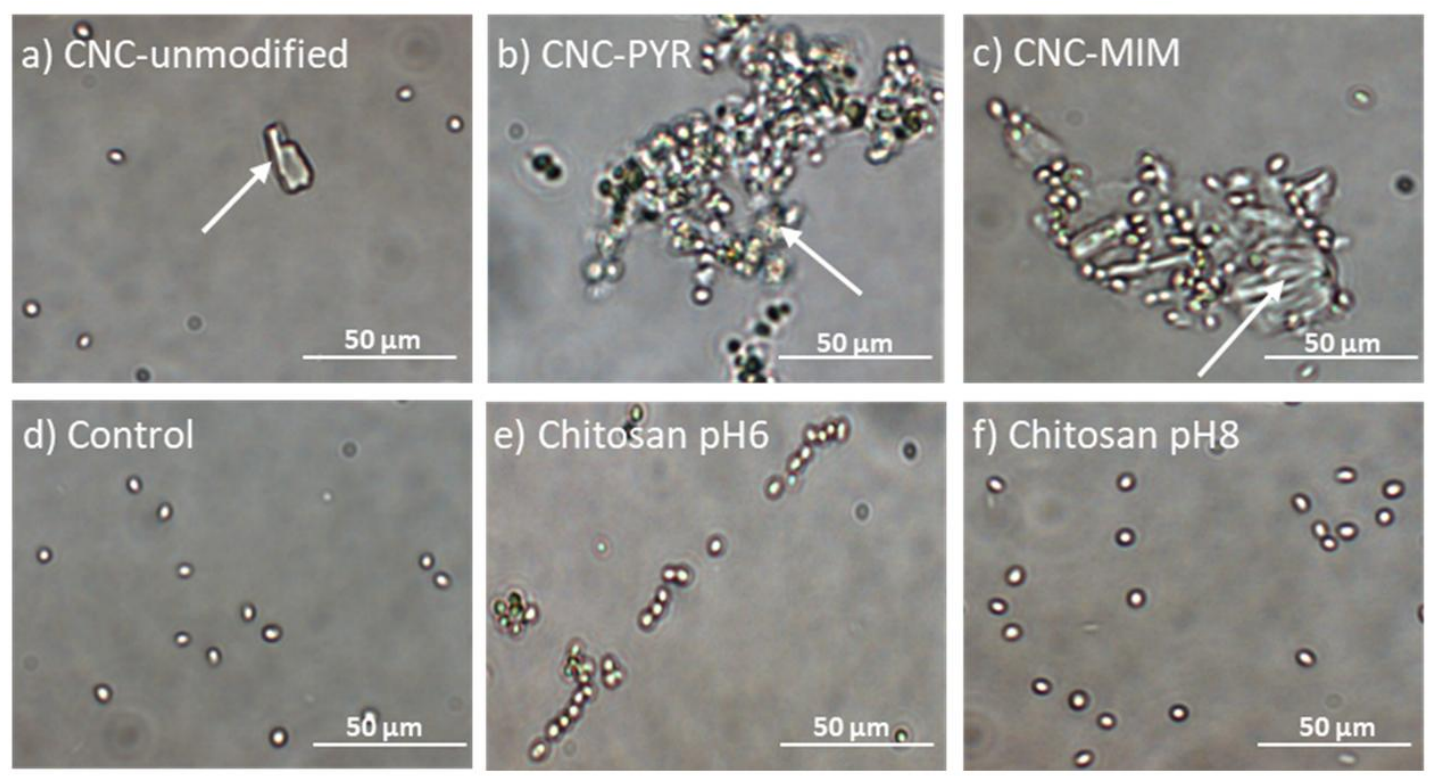

201

202

203

204

205

Figure 2. Optical imaging of $C$. vulgaris flocculation. Optical image of $C$. vulgaris cells after resuspension in PBS containing a) $100 \mathrm{mg} / \mathrm{L}$ of CNC-unmodified at $\mathrm{pH} 8$, b) $100 \mathrm{mg} / \mathrm{L}$ of CNC-PYR at $\mathrm{pH} 8, \mathrm{c}) 100 \mathrm{mg} / \mathrm{L}$ of CNC-MIM at pH 8, d) nothing at pH 6, e) $10 \mathrm{mg} / \mathrm{L}$ of chitosan at $\mathrm{pH} 6$, and f) 10 $\mathrm{mg} / \mathrm{L}$ of chitosan at $\mathrm{pH}$ 8. The arrows in a), b) and c) indicate the CNC particles.

AFM nanoscale scale experiments reveal the role of biological interactions between cells and chitosan during flocculation

To answer this question, we used atomic force microscopy (AFM) in order to directly probe the interactions between the flocculants and cells and to get a better insight into the flocculation mechanisms involved in each case. We first performed force spectroscopy experiments to probe the interactions between CNCs and single $C$. vulgaris cells. For that, a first method (method 1 described in the Methods section, Figure S2a) has consisted in using tips directly modified with CNCs (Figure S3) to probe the interactions with cells immobilized on a positive glass surface at a $\mathrm{pH}$ of 8 . In the case of 
CNCs, the charge present on the particles is not dependent on the $\mathrm{pH}$ because the modified CNCs carry a quaternary ammonium group that is permanently positively charged. But because this first method was difficult to implement for modified CNCs, as the forces recorded between the CNCs particles and cells were stronger than the electrostatic forces between the cells and the surface on which they were immobilized, only a small number of cells could be probed. Indeed, during force spectroscopy, the cells would detach from the surface to adhere to the CNC particle on the probe, therefore making the measurements impossible. To overcome this challenge, we also recorded data using FluidFM technology (method 2 in the Methods section, Figure S2b). In this case, single cells were aspirated at the aperture of microfluidic probes by exerting a negative pressure inside the cantilever microchannel. This negative pressure was sufficient to keep the cells attached to the cantilever, and thus more measurements could be performed. The data presented in Figure 3 combines data obtained with these two methods for modified CNCs (details of these data can be found in Table S3); in the case of unmodified CNCs, only the first method was used. In this figure, the adhesion forces, rupture distances and representative force curves recorded in PBS buffer are presented. The adhesion force corresponds to the strongest adhesion event in each force curve, while the rupture length is the distance of the last adhesion event recorded. The percentage of adhesion indicated corresponds to the percentage of force curves presenting retract adhesions. In each case, the results presented correspond to the interactions recorded with 10 cells coming from at least 2 independent cultures. In the case of unmodified CNCs (Figure 3a and b), and in line with our previous work, no interactions with cells can be observed, as retract force curves show no retract peaks. In the case of CNC-PYR (Figure $3 c$ and d), a single retract peak happening at the contact point can be observed, with in this case an average force of $1.2 \pm 0.7 \mathrm{nN}$ ( $\mathrm{n}=9801$ force curves). This force signature is typical of non-specific interactions, most likely reflecting electrostatic interactions between the negative surface of the cells and the positive surface of PYR-modified CNCs. ${ }^{34}$ Similar

238 force curves could be obtained for CNCs-MIM (Figure 3e and f), however, in this case the average adhesion force recorded was of $3.5 \pm 2.6 \mathrm{nN}$ ( $\mathrm{n}=8845$ force curves), so almost 3 times higher than 
for CNCS-MIM. The adhesion force difference between CNC-MIM and PYR is significant at a p-value of 0.001 (unpaired t-test). This is an interesting point; indeed, CNC-MIM have a higher number of positive charges compared to CNC-PYR, and our results indicate that this difference influence the adhesion force recorded. Thus the more positive charges on the CNCs are present, the stronger the electrostatic bond with the cell's surface is. However, the difference in DS between both cationic CNCs is small (CNCs-PYR, DS $=0.20$ and CNCs-MIM, DS $=0.23$ ), not fully explaining the big differences in adhesion forces. An explanation for these differences might reside in the chemical structure of the cationic grafts on the CNCs. In the CNC-PYR sample, the cationic charge is distributed over a 6membered ring, while only over a 5-membered ring in the CNC-MIM sample, causing different charge densities at the atomic level. Moreover methylimidazolium has two nitrogen atoms in its ring structure, while pyridinium only contains one; this could also contribute to the difference recorded in $\mathrm{nm}$ for CNC-PYR, and of $18.6 \pm 22.1 \mathrm{~nm}$ for CNC-MIM, indicating that no molecules were pulled away from the surface of the cells. Thus, these results confirmed that the interactions between cationic

254 CNCs and cells are non-specific and electrostatic. Hence, this molecular data confirms that in the case

255 of CNCs-induced flocculation a charge neutralization mechanism is involved, and it explains why better flocculation efficiencies are obtained using CNCs bearing a higher number of positive charges. To further prove this point, and exclude possible contributions of other types of interactions between CNCs and cells, additional experiments were carried out to measure the interactions between beads bearing $\mathrm{COOH}$ functionalities, thus negatively charged at a $\mathrm{pH}$ of 8 , and $\mathrm{CNCs}$ immobilized on mica surfaces. These beads have a similar size to the cells, and thus are here used as artificial non-living analogues of microalgae cells bearing only negative charges and no surface

262 polymers. The results (Figure S4) show the same tendency, i. e. single peak retract force curves and 263 lower adhesion values obtained with CNCs-PYR $(5.3 \pm 1.4 \mathrm{nN}, \mathrm{n}=800$ force curves obtained with 2 264 different beads), compared to CNCs-MIM $(49.6 \pm 10.6 \mathrm{nN}, \mathrm{n}=800$ force curves obtained with 2 265 different beads). In this case, the adhesion values are higher than the ones obtained with cells; this 

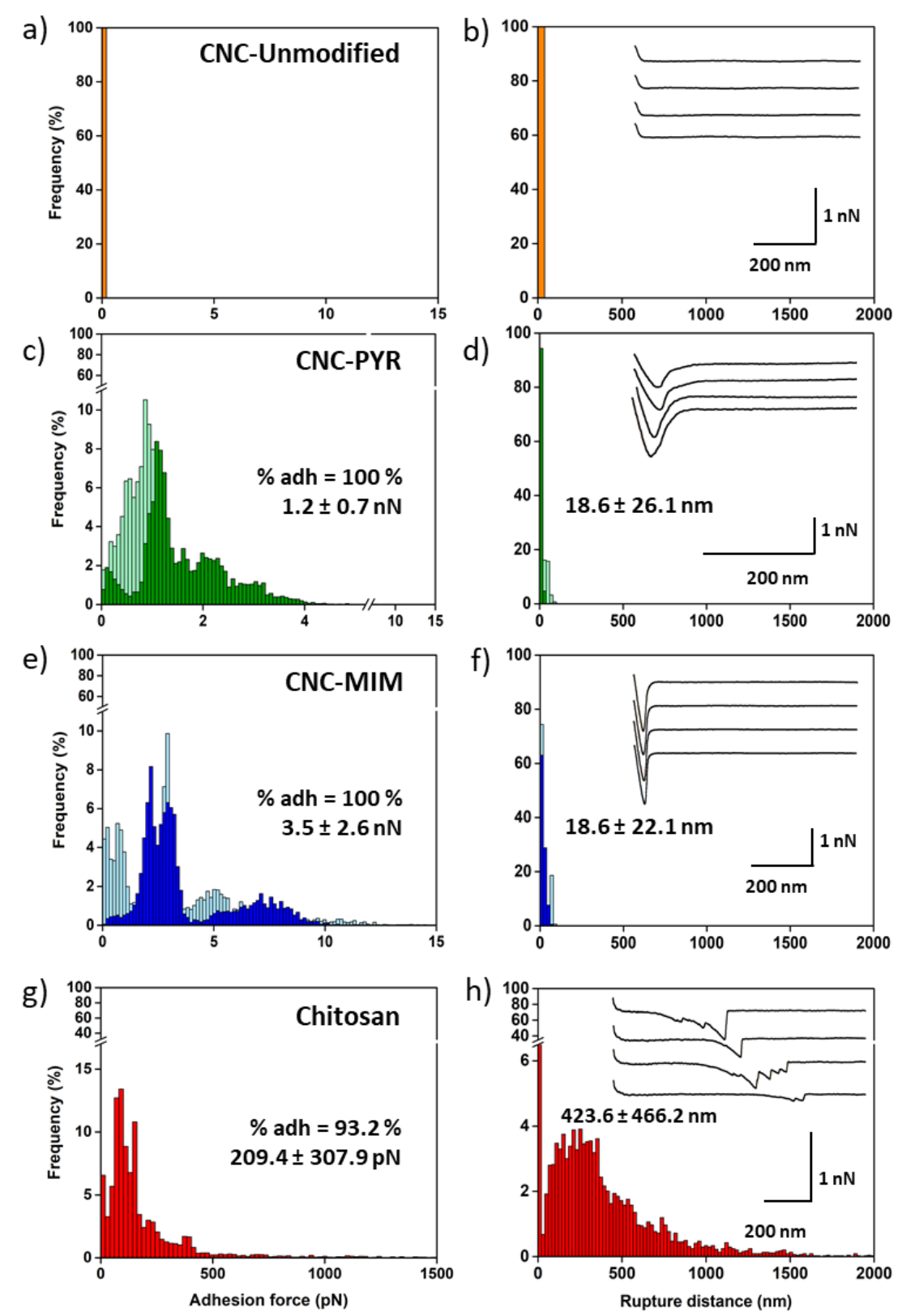

Figure 3. Interactions between $\mathrm{CNCs}$ or chitosan and single $\boldsymbol{C}$. vulgaris cells. a) Adhesion force histogram between $C$. vulgaris cells and CNCs-unmodified at $\mathrm{pH} 8$ and b) corresponding rupture distance histogram. c) Adhesion force histogram between C. vulgaris cells and CNCs-MIM at pH 8 and d) corresponding rupture distance histogram. The light green distributions correspond to values obtained with method 1 and the dark green distributions correspond to values obtained with method 2. e) Adhesion force histogram between $C$. vulgaris cells and CNCs-MIM at pH 8 and f) corresponding rupture distance histogram. The light blue distributions correspond to values obtained with method 1 and the dark blue distributions correspond to values obtained with method 2. g) Adhesion force histogram between $C$. vulgaris cells and chitosan spin-coated on a glass slide at $\mathrm{pH} 6$ and $\mathrm{h}$ ) 
corresponding rupture distance histogram. Insets in b), d), f) and h) show representative force curves obtained. Data were recorded using a set-point of $0.25 \mathrm{nN}$.

However, the interesting result from these force spectroscopy analysis concerns chitosan (Figure $3 \mathrm{~g}$ and $\mathrm{h}$ ). In this case, the interactions between a single living $C$. vulgaris cell immobilized at the edge of a tipless cantilever ${ }^{41}$, and a chitosan-functionalized surface by spin-coating ${ }^{42,43}$ were $^{2}$ probed at a pH of 6 (method 3 in the Methods section, Figure S2c). In this case, retraction force profiles showed multiple binding events with an average adhesion force of $209.4 \pm 307.9 \mathrm{pN}$ ( $\mathrm{n}=$ 5698 force curves), thus much lower than the forces recorded for cationic CNCs. In contrast, the average rupture length for chitosan was $423.3 \pm 466.2 \mathrm{~nm}$, whereas in the case of cell interactions with CNCs it was close to zero. Note that the large standard deviations come from the wide distributions of the values visible on the histograms, caused by the heterogeneity inherent to living cells. The extended ruptures, the low adhesion forces recorded, as well as the lack of defined force patterns are consistent with the stretching of long molecules from the cell wall of cells. ${ }^{44-46}$ Given the difference in the force signatures obtained, our results suggest that in the case of chitosan, even when positively charged, no electrostatic interactions are involved in the bonding with cells, or at least if electrostatic interactions are involved they are not predominant in the interactions and are masked by the biological interactions. This inherently implies that chitosan is able to interact specifically with polymers present at the surface of cells that are then unfolded upon retraction in our force spectroscopy experiments, resulting in the long rupture distances observed. Taking into account the work of Cheng and coworkers, who showed that the carbohydrate composition of the cell wall of $C$. vulgaris has a direct influence on the efficiency of flocculation obtained with chitosan ${ }^{32}$, we may suggest that chitosan is able to specifically interact with these polysaccharides. Moreover, similar force patterns were already observed for microalgae by Higgins and coworkers who extended mucilage (composed of polysaccharides) from the cell wall of Craspedostauros australis, a marine diatom, and of Pinnularia viridis, a freshwater diatom ${ }^{47}$. This further supports that the unfolding observed in our case may be due to the unfolding of polysaccharides from the $C$. vulgaris cell wall. For the moment, such specific structural interactions between chitosan and polysaccharides, not 
dependent on electrostatic interactions, have been described only in a few cases, for example with cellulose ${ }^{48}$ or with alginate, ${ }^{49}$ for which interactions with chitosan have been observed at high or low $\mathrm{pH}$, where either the polysaccharides or the chitosan are uncharged. Moreover, previous studies have also reported the possible interaction between chitosan and glycopolymers in the case of microorganism flocculation: for example Barany et al. showed that Escherichia coli flocculation by chitosan relied on chitosan absorption to polymers from the cells, rather than on electrostatic factors. ${ }^{50}$ Thus, at this stage, the data obtained indicate that chitosan flocculation at $\mathrm{pH} 6$ in the case of C. vulgaris does not occur through electrostatic interactions, but rather through biological interactions, meaning that chitosan interacts with biomolecules at the cell surface that are then unfolded from the cell surface. These biomolecules might be polysaccharides present at the surface of the cells. More questions can now be raised: can further data prove this? Is this mechanism also at play at $\mathrm{pH} 8$ ?

\section{Chitosan induced-flocculation of $C$. vulgaris at higher $\mathrm{pH}$ does not occur through the same} mechanism

To further investigate the flocculation mechanism of chitosan, we decided to compare the interactions between chitosan and cells at pH 6 and 8 at varying applied forces. When the applied force is increased during force spectroscopy experiments, because the chitosan layers are deformable (Ym of $15.6 \pm 30.5 \mathrm{kPa}$ at $\mathrm{pH} 6, \mathrm{n}=1554$ force curves, and of $19.2 \pm 23.2 \mathrm{kPa}$ at $\mathrm{pH} 8$, $\mathrm{n}=1349$ force curves, values extracted from force curves at an indentation segment of $100 \mathrm{~nm}$, data not showed), the contact area between the cells and the chitosan surface increases as well. This increase should lead to higher adhesion forces as more molecules from the cell wall are able to interact with the chitosan surface; rupture lengths will also provide useful information on the nature of the molecules unfolded. The results of these experiments are presented in Figure 4, they were obtained in the case of a set point of $0.25 \mathrm{nN}$ with 10 different cells, and in the case of higher set points with 4 different cells coming from at least 2 independent cultures (details of the data can be 
found in Table S3, S4 and S5). In each case, the differences between the adhesion forces recorded at

$334 \mathrm{pH} 6$ and $\mathrm{pH} 8$, for the different set-points, are significantly different at a p-value of 0.001 (unpaired

335 t-test). At pH 6, we can observe that the more the applied force was increased, the more the average adhesion force increased, from $209.4 \pm 307.9 \mathrm{pN}$ at an applied force of $0.25 \mathrm{nN}$ (Figure $4 \mathrm{a}, \mathrm{n}=5698$ force curves), to $296.6 \pm 327.1 \mathrm{pN}$ at $1 \mathrm{nN}$ (Figure $4 \mathrm{c}, \mathrm{n}=2050$ force curves) and $444.9 \pm 398.9 \mathrm{pN}$ at $2 \mathrm{nN}$ (Figure 4e, $\mathrm{n}=2050$ force curves), thus two times higher. As for the rupture distances, they also increase with the applied force, from in average $423.6 \pm 466.2 \mathrm{~nm}$ at $0.25 \mathrm{nN}$ (Figure $4 \mathrm{~b}$ ) up to 679.7 $\pm 523.3 \mathrm{~nm}$ at $2 \mathrm{nN}$ (Figure 4f). This thus indicates that as the contact surface area increases between the cell and the chitosan surface, the more molecules, probably polysaccharides, from the cell wall involved in the interactions with chitosan were extended, resulting in higher adhesion forces and rupture distances. When these experiments were performed at a $\mathrm{pH}$ of 8 , a similar trend was observed, with an increase in both the maximum adhesion force and rupture length when the applied force is higher. However, an interesting point to note in this case is the difference in values between the measurements performed at $\mathrm{pH} 6$ and $\mathrm{pH} 8$. Indeed, in the case of $\mathrm{pH} 8$, the average adhesion force recorded was $193.1 \pm 182.8 \mathrm{pN}$ at an applied force of $2 \mathrm{nN}$ (Figure $4 \mathrm{k}, \mathrm{n}=2050$ force curves), thus almost equivalent to the adhesion force recorded at $\mathrm{pH} 6$ for the smallest applied force (0.25 nN). Regarding rupture lengths, although the average distances recorded were similar at a high force applied, their difference is important at a low applied force $(423.6 \pm 466.2 \mathrm{~nm}$ at pH 6 and $320.9 \pm 362.5 \mathrm{~nm}$ at $\mathrm{pH}$ 8). The differences in these values are surprising as one would expect that if the interaction mechanism is indeed based on biological interactions, the same molecules would unfold from the cell surface irrespective of the $\mathrm{pH}$, resulting in similar unfoldings with similar rupture 

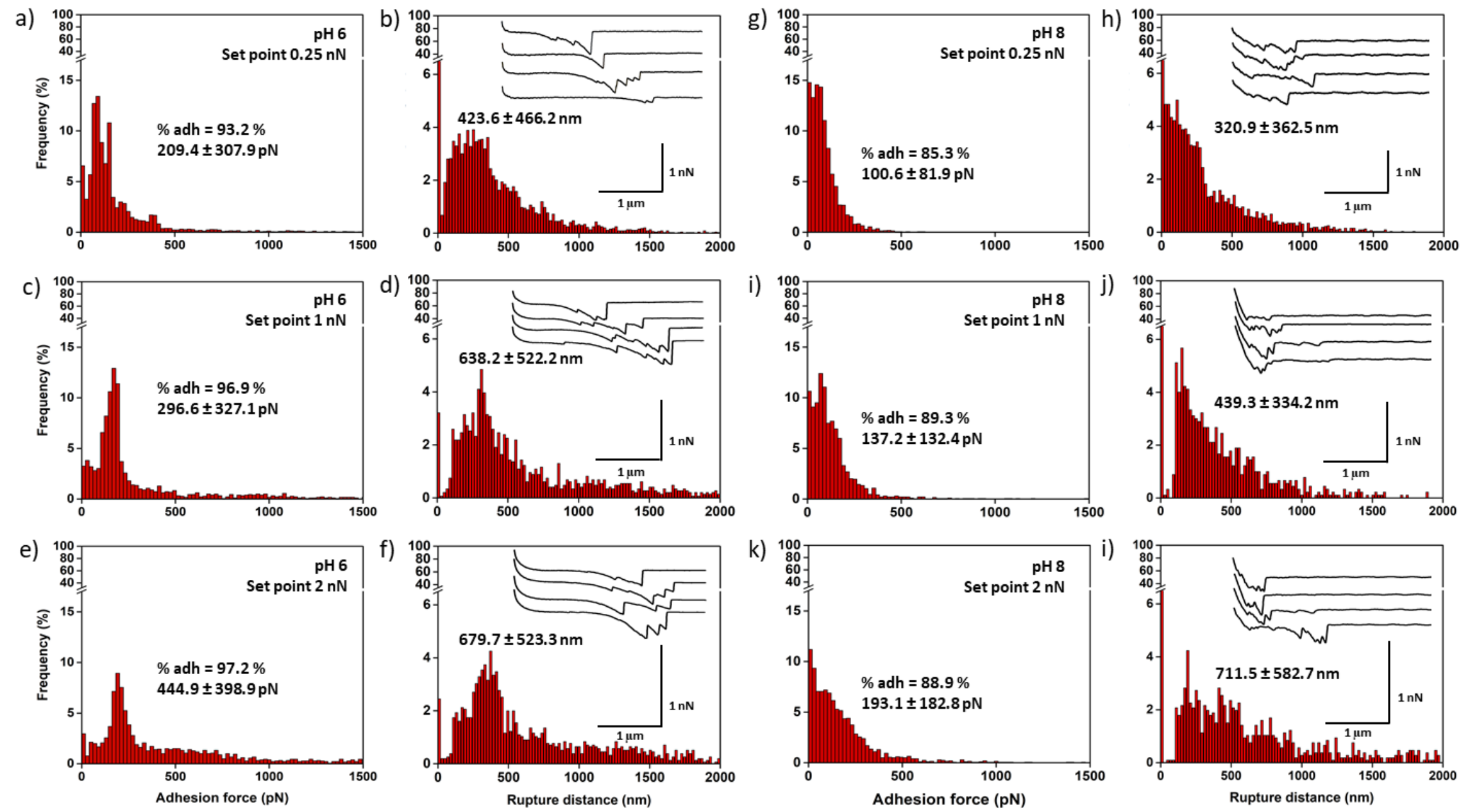

Figure 4. Interaction between chitosan and single $C$. vulgaris cells at pH 6 and 8 at varying applied forces. a) Adhesion force histogram and b) corresponding rupture distance histogram betweens a $C$. vulgaris cell-functionalized cantilever and chitosan spin-coated on a glass slide at pH 6 using a setpoint of $0.25 \mathrm{nN}, \mathrm{c}$ ) and d) using a set-point of $1 \mathrm{nN}$, e) and f) using a set-point of $2 \mathrm{nN}$. g) Adhesion force histogram and h) rupture distance histogram between a . vulgaris cell-functionalized cantilever and chitosan spin-coated on a glass slide at pH 8 using a set-point of $0.25 \mathrm{nN}$, i) and j) using a set-point of $1 \mathrm{nN}, \mathrm{k}$ ) and I) using a set-point of $2 \mathrm{nN}$. Insets in b), d), f), h), j) and I) show representative force curves obtained. 
362 probed the interactions with chitosan surfaces at pH 6 and 8 . The results are presented in Figure 5.

363 At $\mathrm{pH} 6$, few interactions were recorded between the beads and the chitosan surface (2.8 \% of the force curves), as most retract force curves present no retract peaks (Figure 5a and b). This thus proves our first hypothesis that chitosan interactions with cells do not rely dominantly on electrostatic interactions but on biological interactions. Indeed, $\mathrm{COOH}$ beads enables us to mimic the cell surface by bearing negative charges, but have the advantage to exclude the molecules that are present on the cell walls. In this case, it is clear that the biological polymers that are present on the microalgal cell surface are essential for the interaction of chitosan with the cell, and that the charge of chitosan is not dominant in the interaction with cells in our experimental conditions. Moreover, as

371 for experiments where the interactions between cells and chitosan were probed at pH 6 (Figure 4),

372 no electrostatic interactions were recorded. This further indicates that these interactions, either do 373 not take place or are smaller than the limit of detection of AFM ( $20 \mathrm{pN})$, and thus cannot be 374 captured. This is an interesting point because at pH 6 chitosan is positively charged, and should in 375 theory interact with negatively charged surfaces; thus perhaps these interactions are too weak to be detected. The poor strength of electrostatic interactions between positively charged chitosan at low $\mathrm{pH}$ and negative surfaces has already been described in other research fields. For example, chitosan has been used to bind with negatively charged drugs in order to form drug loaded chitosan nano- and may be poor. ${ }^{51}$ 

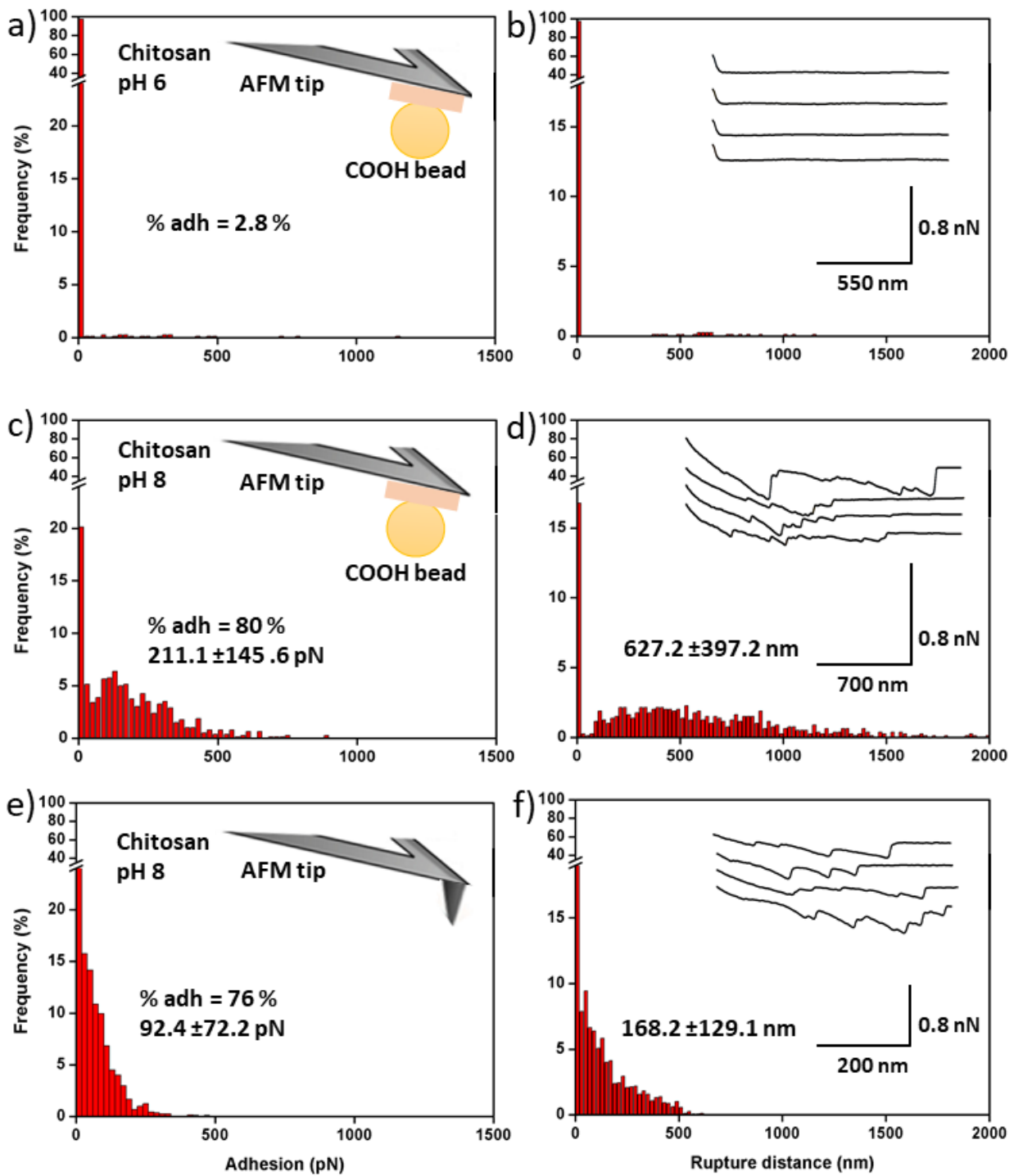

Figure 5. Interaction between bare tips and negative beads-functionalized cantilevers with chitosan surfaces. a) Adhesion force histogram between a $\mathrm{COOH}$ bead-functionalized cantilever and chitosan spin-coated on a glass slide at $\mathrm{pH} 6$ and b) corresponding rupture distance histogram. c) Adhesion force histogram between a $\mathrm{COOH}$ bead-functionalized cantilever and chitosan spin-coated on a glass slide at $\mathrm{pH} 8$ and d) corresponding rupture distance histogram. e) Adhesion force histogram between a bare AFM tip chitosan spin-coated on a glass slide at $\mathrm{pH} 8$ and f) corresponding rupture distance histogram. Insets in b) d) and f) show representative force curves obtained. Data were recorded using a set-point of $0.25 \mathrm{nN}$.

When the same experiments are performed at a pH of 8 (Figure $5 \mathrm{c}$ and d), force curves show multiple peaks that have a similar profile to the ones obtained using cells instead of beads, with average adhesion forces and rupture lengths recorded values of $211.1 \pm 145.6 \mathrm{pN}$ and $627.2 \pm 397.2$ $\mathrm{nm}$ ( $\mathrm{n}=800$ force curves, with 2 different beads), respectively. Using bare tips instead of beads (Figure $5 e$ and $\mathrm{f}$ ), the same unfolding events were recorded, with similar adhesion and rupture 
distances values as in the case of cells. This result is unexpected: indeed, the bare tips used, as for the beads, carried no polymers, i.e. the multipeaks observed on the force curves must correspond to the unfolding of chitosan picked up directly from the surface upon retraction by the tips or the beads. This indicates that at this $\mathrm{pH}$, the structure of chitosan must be different than at $\mathrm{pH} 6$ where bare tips do not allow the unfolding of chitosan. Moreover, this gives the explanation for the results obtained using living cells at pH 8 (Figure 4g-l): in this case also, the chitosan must be unfolded from the surface which explains why the adhesion forces and rupture lengths values obtained are different from those obtained at $\mathrm{pH} 6$. Given the fact that the same chitosan unfoldings were obtained with cells, negative beads or bare tips, we can thus conclude that at $\mathrm{pH} 8$ there is no biological nor electrostatic interaction between the cells and chitosan, in agreement with the optical images obtained (Figure 2e) where no cell aggregation could be visualized. The fact that higher adhesions and rupture lengths values are recorded with beads compared to cells or bare AFM tips is explained by the fact that the surface contact with beads is larger (6-7 $\mu \mathrm{m}$ of diameter compared to 3-4 $\mu \mathrm{m}$ of diameter for cells), thus allowing the AFM tip to pull more chitosan from the surface. The flocculation mechanism of cells at $\mathrm{pH} 8$ is thus based on a different mechanism than at $\mathrm{pH} \mathrm{6;} \mathrm{our}$ hypothesis is that at this $\mathrm{pH}$, the chitosan precipitates and flocculates the cells by sweeping, as we have demonstrated in our previous study. ${ }^{31}$ We now need to verify this hypothesis.

\section{Sweeping mechanism is involved in the flocculation of $C$. vulgaris at $\mathrm{pH} 8$}

The previous results have demonstrated that cells do not interact through biological or electrostatic interactions with chitosan at $\mathrm{pH}$ 8. However, the question is now to understand if this is due to changes in the cell wall properties of the cells, to changes in the chitosan structure, or to both? It has been shown previously with the marine species Phaeodactylum tricornutum that the cell wall rigidity changed with $\mathrm{pH}$, which impacted on the deformability of the cells and thus on their interactions with their environment. ${ }^{34}$ Moreover, AFM studies on microorganisms have shown that under some conditions, the architecture and network of molecules at the surface of cells can change 
depending on the external conditions, which thus impacts on the availability of molecules to interact with their environment. ${ }^{45}$ To verify these two points in our study, we performed nanomechanical analysis of the cell wall of cells as well as surface roughness analysis. These results are presented in Figure 6. To obtain quantitative information on the nanomechanical properties of the cells, we determined the Young modulus $(\mathrm{Ym})$ of the microalgae cells trough nanoindentation measurements, in PBS at pH 6 and $\mathrm{pH} 8$ (Figure $6 \mathrm{a}$ and b). In this type of measurements, the cantilever, for which mechanical properties are known, is pressed against the cells at a given force. This enables us to extract the Ym of the cell wall, a parameter that reflects its resistance to compression (the higher the Young modulus value, the more rigid the cell wall). Nanoindentation measurements, which give access to force vs distance curves, were performed on areas of $500 \mathrm{~nm} \times 500 \mathrm{~nm}$ on top of cells, on 8 cells coming from at least 2 independent cultures. Ym values were then obtained first by converting the force curves obtained into force vs indentation curves, shown in Figure 6a, and then by fitting them with a theoretical model, in our case, the Hertz model ${ }^{52}$ (black empty circles on the curves in Figure 6a). The results show that the indentation curves obtained on cells at $\mathrm{pH} 6$ and 8 are different; indeed, the AFM probe is able to indent deeper into cells at $\mathrm{pH} 6$ than at $\mathrm{pH} 8$, meaning that increasing the $\mathrm{pH}$ also increases the rigidity of the cell wall. Quantitative analysis of the $\mathrm{Ym}$ extracted from thousands of these curves on 8 cells in each case confirmed this finding, and showed that at $\mathrm{pH}$ 6, cells have an average $\mathrm{Ym}$ of $232.9 \pm 175.6 \mathrm{kPa}$ ( $n=8192$ force curves), whereas cells at $\mathrm{pH} 8$ have a Ym of $750.2 \pm 589.0 \mathrm{kPa}$ ( $n=8182$ curves, differences are significant at a $p$-value of 0.001 , unpaired $t$ test, details can be found in table S6). While the nanomechanical properties of $C$. vulgaris have never been determined using AFM before, these values are in the range of Ym values obtained on other microorganisms such as yeasts, that have a cell wall composition comparable to microalgae. ${ }^{53}$ Moreover, this increase in the rigidity, due to the increase of $\mathrm{pH}$, has already been shown in the case of $P$. tricornutum. ${ }^{34}$ Hence, increasing the $\mathrm{pH}$ changes the nanomechanical properties of the cell wall and thus its architecture, perhaps explaining in part the fact that cells are not able to interact with chitosan at $\mathrm{pH}$ 8. Indeed, it could mean that the molecules involved in the interaction with chitosan 
are not available anymore for interaction, or that their conformation at elevated $\mathrm{pH}$ prevents the interaction with chitosan. Regarding the cell wall roughness, this parameter was directly extracted from contact images of $500 \mathrm{~nm} \times 500 \mathrm{~nm}$ obtained on top of 8 cells coming from at least 2 independent cultures. The results obtained (Figure 6c-f) show that the surface morphology is slightly modified by the increase in $\mathrm{pH}$, as shown by the vertical deflection images recorded on top of the cells in Figure $6 c$ and $d$. Cross-sections taken along the white lines in Figure $6 c$ and $d$ show this difference, as the profile of this cross-section at $\mathrm{pH} 8$ presents larger motives. The quantitative analysis of the roughness measured on several cells showed that at $\mathrm{pH} 6$, cells have an average roughness of $0.9 \pm 0.5 \mathrm{~nm}$ while it increased to $1.7 \pm 0.9 \mathrm{~nm}$ at $\mathrm{pH} 8$. While this difference is significant, it remains low and indicates that at $\mathrm{pH} 8$, more molecules protrude from the surface of the cell, which might mask the molecules involved in the interaction with chitosan, or perhaps might indicate that these molecules are coiled and not able to interact anymore. ${ }^{45}$ Overall this biophysical analysis of the cell wall of $C$. vulgaris indicates that a $\mathrm{pH}$ increase from 6 to 8 clearly affects its rigidity and its roughness. These changes, as discussed, may explain why cells do not interact with chitosan anymore at $\mathrm{pH} 8$.

(1)

(1)



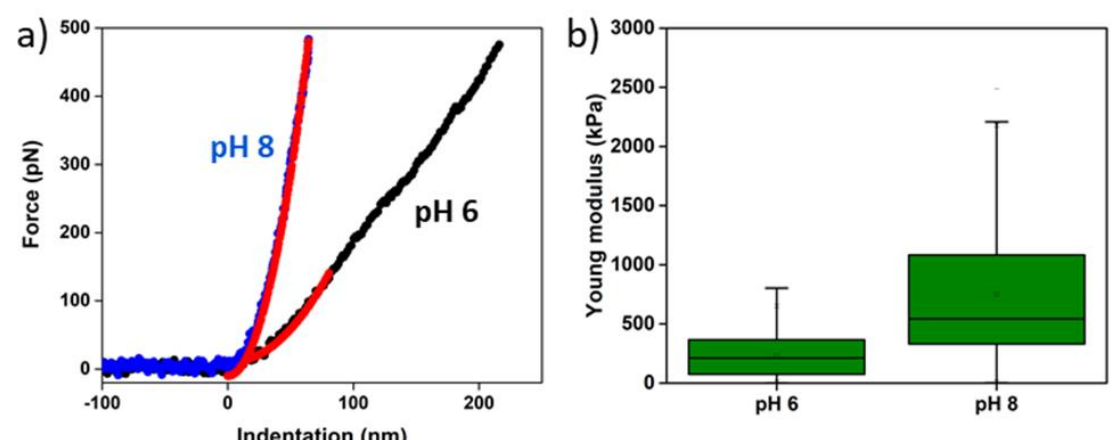

c)

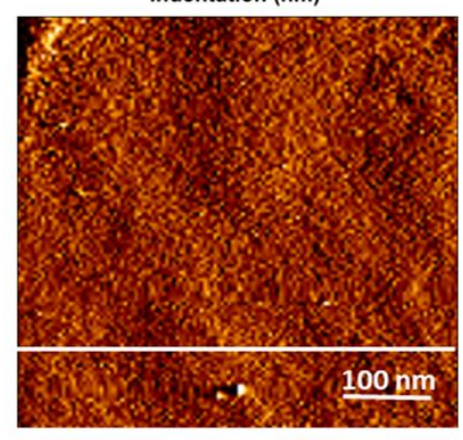

d)
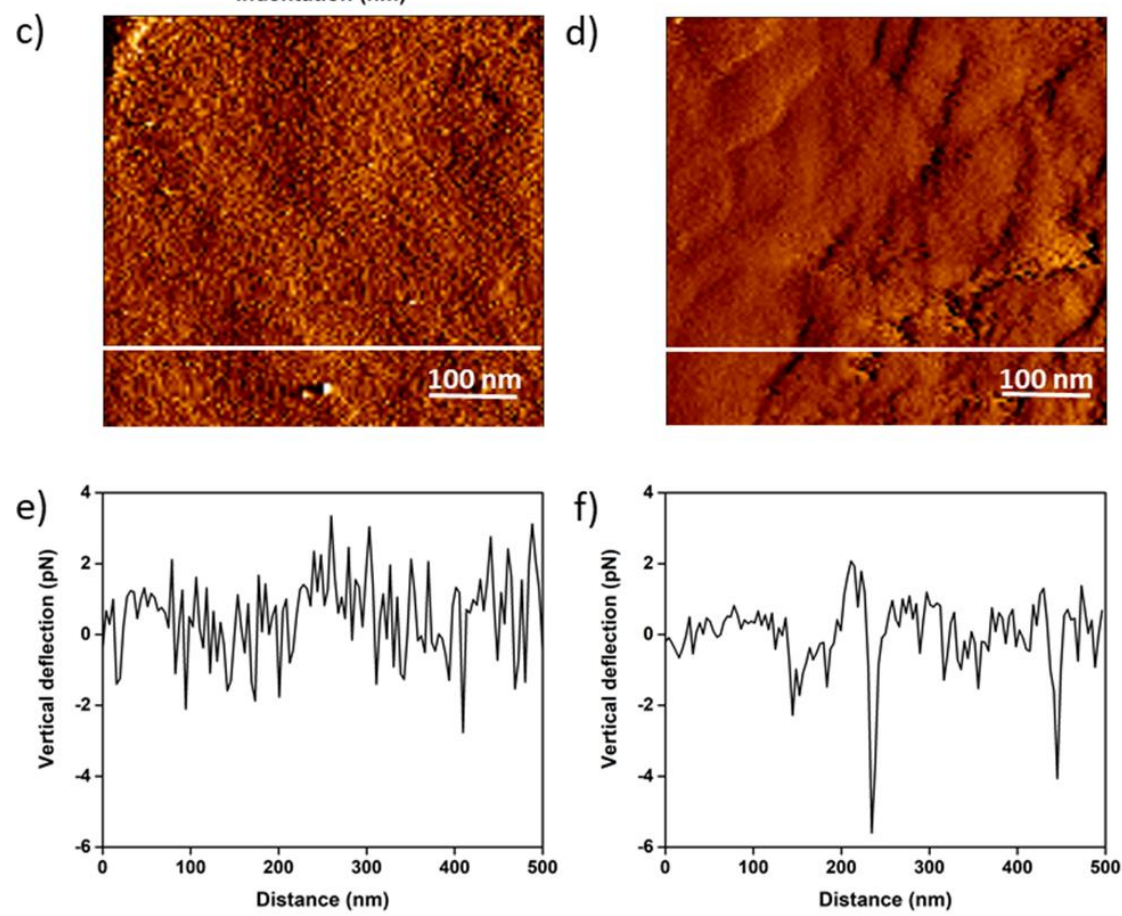

Figure 6. Nanomechanics and cell wall roughness of the $C$. vulgaris cell wall. a) Indentation curves (blue and black lines) fitted with the Hertz model at $80 \mathrm{~nm}$ of indentation (red lines) recorded on top of $C$. vulgaris cells at pH 6 and 8. b) Boxplot of the Young's modulus values measured on top of $C$. vulgaris cells at $\mathrm{pH} 6$ and 8. c) Vertical deflection AFM image of an area $(500 \times 500 \mathrm{~nm})$ of the cell surface at pH 6 and d) vertical deflection AFM image of an area $(500 \times 500 \mathrm{~nm})$ of the cell surface at $\mathrm{pH}$ 8. e) Cross-section taken along the white line in c) and f) cross-section taken along the white line 


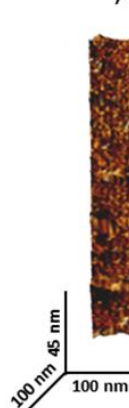

b) $\mathrm{pH} 8$

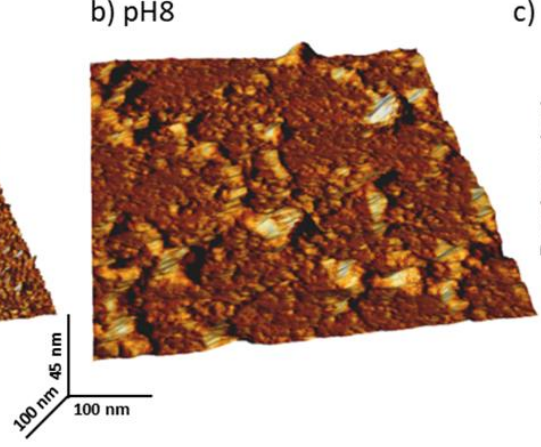

c)

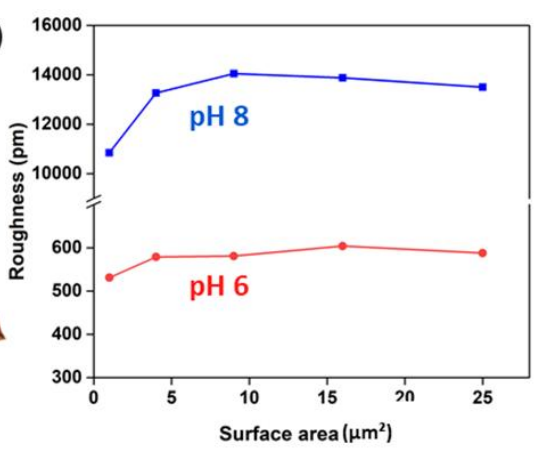

501 structure of chitosan itself caused by its precipitation.

502 Figure 7. Characterization of chitosan surfaces at two different pH. a) 3D AFM height image of

503

504

505

506 chitosan surface at $\mathrm{pH}$ 6. b) 3D AFM height image of chitosan surface at $\mathrm{pH}$ 8. c) Quantification of chitosan surface roughness at $\mathrm{pH} 6$ and 8.

\section{CONCLUSION}

Chitosan, given its many advantages, has been widely used as a flocculant to efficiently harvest diverse species of microalgae. Since understanding the flocculation mechanisms is key to control them and use them in larger-scale processes, the case of chitosan has generated a lot of debate in the scientific community. Indeed, while for freshwater species that grow at $\mathrm{pH}$ below 6.5 , chitosan-induced flocculation is believed to rely on a charge neutralization mechanism, some studies also show it becomes more efficient at higher $\mathrm{pH}$, while in marine waters were the salts present screen the charges of chitosan, chitosan can still flocculate microalgae. It is therefore of great importance to provide new data, using original techniques, to finally shed light on the flocculation 
mechanism at play. For that we have chosen the freshwater green species, $C$. vulgaris, and studied at the nanoscale its interactions with chitosan using atomic force microscopy. Our results demonstrate that depending on the $\mathrm{pH}$, the interaction mechanism is different, which reveals the complexity of chitosan flocculation. Indeed, preliminary macroscopic observations suggest that the charge of chitosan is not involved in the interaction with cells, as different degrees of deacetylation result in the same flocculation efficiency at $\mathrm{pH} 6$. At increased $\mathrm{pH}$, for the same degree of deacetylation, the flocculation behavior is different as high doses of chitosan still allow an efficient separation, which is not the case at $\mathrm{pH} 6$. Based on these observations, our force spectroscopy experiments show that at pH 6, chitosan interacts in a specific way with most probably polysaccharides present on the surface of cells, and that the chitosan charge is not significantly involved in these interactions. This was confirmed by comparing these data with those obtained for cationically modified CNCs, for which a previous study has demonstrated the contribution of only of charge neutralization in the flocculation mechanism. ${ }^{37}$ However, such biological interactions between chitosan and the surface of cells could not be detected at $\mathrm{pH}$ 8. Indeed, biophysical analysis of the cell wall of $C$. vulgaris cells, as well as roughness analysis of the chitosan used in this study suggest that at this $\mathrm{pH}$, both the architecture of the cell wall and the structure of chitosan are modified, resulting in an absence of interactions with the cells. Based on a previous work published last year where we had found that a sweeping mechanism is involved in the chitosan-induced flocculation of $\mathrm{N}$. occulata at high $\mathrm{pH}$, we thus suggest that this mechanism is also at play for the flocculation of $C$. vulgaris at high $\mathrm{pH}$. These different mechanisms of flocculation are depicted in Figure 8. This study thus represents an original contribution to the field of microalgae harvesting as molecular-scale data allow in this case to understand the flocculation mechanisms and to show the important influence of the culture medium $\mathrm{pH}$ on these mechanisms. Therefore, this work brings important information that will help in implementing chitosan-induced flocculation to harvest microalgae at large-scale. Further work is now needed to identify the polymers from the cell surface that interact specifically with chitosan at $\mathrm{pH} 6$. Because a large amount of microalgae species share the same surface characteristics, in particular 
541 the composition, this knowledge would make it then be possible to perform efficient chitosan

542 flocculation with a wide range of microalgae species.

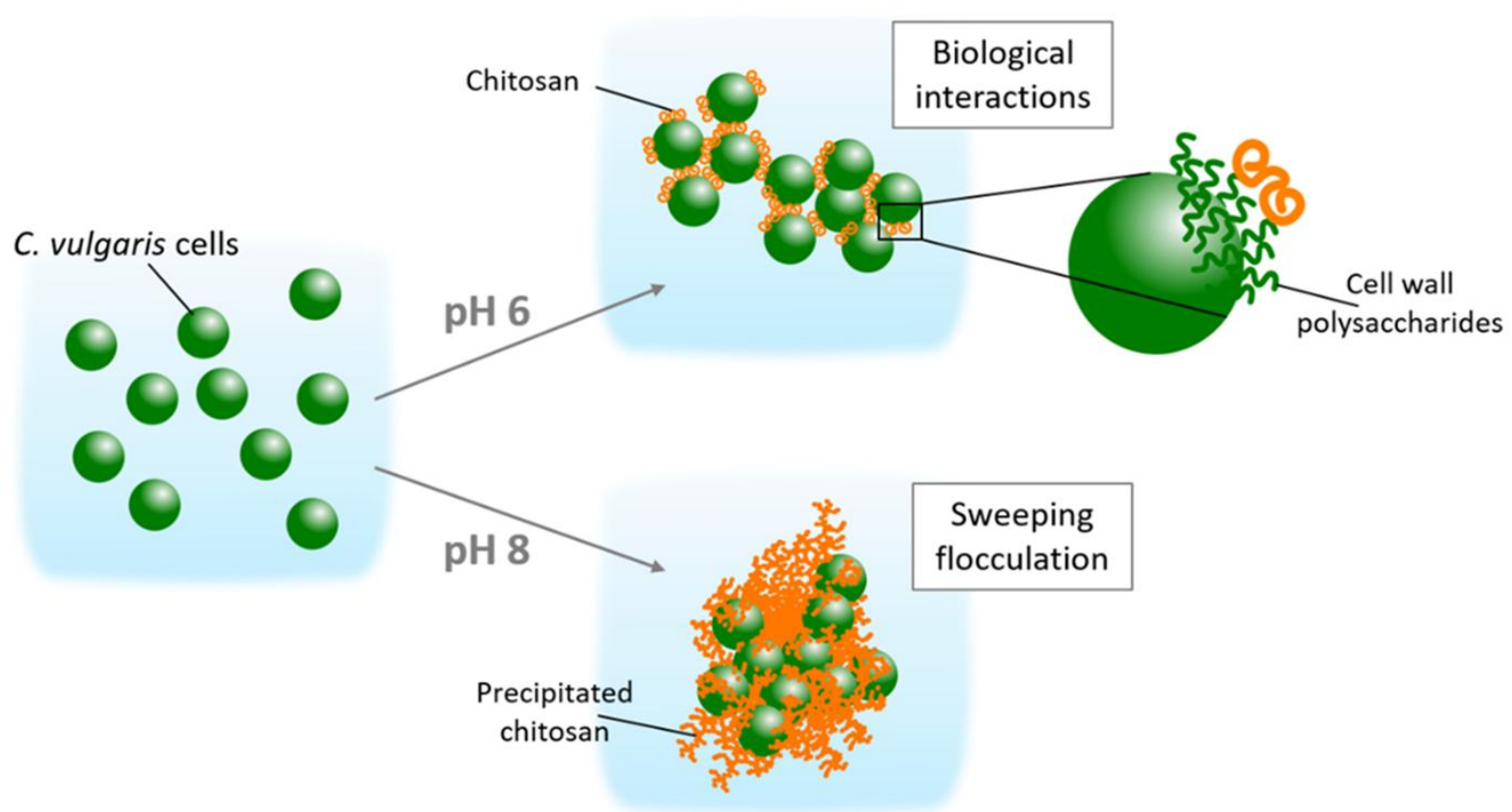

Figure 8. Schematic representation of the flocculation mechanisms induced by chitosan at pH 6 and 8 for C. vulgaris.

METHODS

Microalgae cultivation. The green freshwater microalgae Chlorella vulgaris strain CCAP 211/11B

(Culture Collection of Algae and Protozoa) was cultivated in sterile conditions in Wright's cryptophyte

552 (WC) medium prepared in deionized water, adjusted to a pH of $7.8 .^{54}$ Cells were cultivated at $20^{\circ} \mathrm{C}$, under agitation (120 rpm), in $1 \mathrm{~L}$ Erlenmeyer ( $300 \mathrm{~mL}$ of culture) flasks. The incubator was equipped with white neon light tubes providing illumination of approximately $40 \mu \mathrm{mol}$ photons $\mathrm{m}^{-2} \mathrm{~s}^{-1}$ with a photoperiod of $18 \mathrm{~h}$ light: $6 \mathrm{~h}$ dark. All experiments were carried out with exponential phase batch cultures (day 7).

Cationically-modified cellulose nanocrystals (CNCs) synthesis. N-Benzylmethylimidazolium Grafted 
559 ([Br] $][B n P y]-g-C N C s$, referred in the text as CNCs-PYR), were synthesized and characterized in a 560 previous study and described in Blockx et al. ${ }^{37}$ For the CNCs-MIM, the sample with a degree of 561 substitution (DS) of 0.23 was used, whereas for the CNCs-PYR, the sample with a DS of 0.20 was used.

562 Chitosan. Three different types of chitosan were used in this study. Commercial chitosan was 563 purchased from Sigma Aldrich (from shrimp, practical grade, $\geq 75 \%$ degree of deacetilation (DD)). In an earlier study it was determined that this chitosan has a $M_{n}$ and $M_{w}$ of 151.3 and $345.2 \mathrm{kDa}$ respectively, and a polydispersity of $2.28^{31}$. This chitosan was used throughout the paper for the flocculation experiments and all AFM experiments. For flocculation experiments, two chitosan samples with different DD (labelled as $70-75 \%$ and $80-85 \%$ ) were prepared from shrimp shells and kindly provided by Nha trang University, Vietnam. Chitosan stock solutions were produced by dissolving $5 \mathrm{~g} / \mathrm{L}$ of the three types of chitosan in $0.04 \mathrm{M}$ of HCl, while stirring $(1000 \mathrm{rpm}$ ) at ambient conditions for 2 hours. A more exact degree of deacetylation was determined for the three chitosan 571 samples via conductometric titrations (Metrohm 856 Conductivity Module and 801 Stirrer with 572 TiamoTM software). For that, $2 \mathrm{~mL}$ stock solution was diluted 50 fold in MiliQ water and titrated with $5735.75 \mathrm{mM} \mathrm{NaOH}$ under constant stirring. The results are shown in supplementary Figure S1 and Table 574 S1. The DD was determined from the volume of $\mathrm{NaOH}$ required to neutralize the chitosan (plateau area of the curves), where each chitosan sample was measured three times. The DD of the commercial Sigma Aldrich chitosan is of $77.5 \pm 0.8 \%$, and for the chitosan samples provided by the Nha trang University of $80.5 \pm 1.4 \%$ and $85.2 \pm 0.2 \%$. The dynamic viscosity of the three chitosan samples was measured on a AR-G2 rheometer (TA Instruments) equipped with a steel double wall couette cell. The experiment consisted of four steps. Step 1: $60 \mathrm{~s}$ at a shear rate of 100.0 /s to allow the sample to set in the sample holder; Step 2: $180 \mathrm{~s}$ at a shear rate of $1.0 / \mathrm{s}$; Step 3: $180 \mathrm{~s}$ at a shear rate of 10.0 /s; and Step 3: $180 \mathrm{~s}$ at a shear rate of 100.0 /s. All experiments were carried out at $25^{\circ} \mathrm{C}$ 582 and 1 datapoint was collected per second. All samples were measured in triplicate. Data analysis was 583 performed with TA Instrument Trios Version 3.3.1.4364. The results are showed in Supplementary Table S2. 
Flocculation experiments. Flocculation of $C$. vulgaris was performed using standardized jar tests

586

587

588

589

590

591

592

593

594

596

597

598

599

600

601

602

603

604

605

606

607

608

experiments. The microalgae suspension was adjusted to a pH of 6 and the initial optical density $\left(\mathrm{OD}_{\mathrm{i}}\right.$, $750 \mathrm{~nm}$ ) was set at 0.7 (corresponding to $0.28 \mathrm{~g} / \mathrm{L}$ ). $50 \mathrm{~mL}$ tests samples were taken and intensively stirred at $550 \mathrm{rpm}$ to mix the suspension. Different concentrations of chitosan were then added $(0,1$, $3,7,10,15,20,40,70,150 \mathrm{mg} / \mathrm{L}$ ) from the $5 \mathrm{~g} / \mathrm{L}$ stock solutions and the suspensions were stirred at $200 \mathrm{rpm}$ for $20 \mathrm{~min}$ to induce flocculation. The suspensions were subsequently decanted in falcon tubes and allowed to settle for 30 min before measuring the optical density after settling $\left(O D_{f}\right)$ of the supernatant (at approximately $3 \mathrm{~cm}$ below the surface). The flocculation efficiency $\left(\eta_{\mathrm{a}}\right)$ was calculated according to the following equation 1 . For experiments at $\mathrm{pH} 8$, the microalgae suspension was adjusted to a $\mathrm{pH}$ of 8 priori to flocculation experiments and the chitosan concentrations used were of $0,3,7,10,15,25,40,70,100,150 \mathrm{mg} / \mathrm{L}$.

$$
\eta_{a}=\frac{O D_{i}-O D_{f}}{O D_{i}}
$$

Optical imaging experiments. Flocculation was directly observed after resuspension of the cells in Phosphate Buffer Saline (PBS) at a pH of 6 or 8 containing chitosan at a concentration of $10 \mathrm{mg} / \mathrm{L}$ or CNCs-PYR or CNCs-MIM, both at a concentration of $100 \mathrm{mg} / \mathrm{L}$. Flocculation levels were observed using an Axio Observer Z1 microscope (Zeiss, Germany) at a magnification of 50x.

Zeta potential experiments. The global electrical properties of $C$. vulgaris cell surface as well as of negative beads ( $\mathrm{COOH}$ functionalized polystyrene beads diameter of $6.83 \mu \mathrm{m}$, Spherotech, USA) were assessed by measuring the electrophoretic mobility with an automated laser zetameter (Zetasizer NanoZS, Malvern Instruments). To this end, microalgae were harvested by centrifugation (3000 rpm, $3 \mathrm{~min}$ ), washed two times in PBS at a $\mathrm{pH}$ of 6 or 8 , and resuspended in the same solution at a final concentration of $1.5 \times 10^{6}$ cell $/ \mathrm{mL}$. In the case of beads, they were first centrifuged ( $3 \mathrm{~min}, 13000$ rpm) and washed two time in deionized water. For each condition, analysis was performed in triplicate. 
610 Nanowizard III AFM (Bruker, USA), with triangular tipless NP-O10 probes (Bruker, USA, nominal spring constant of $0.06 \mathrm{~N} / \mathrm{m}$ and of $0.2 \mathrm{~N} / \mathrm{m}$ ).

Functionalization with CNCs: Colloidal probes were functionalized with cationic CNC particles.

Colloidal probes were obtained by attaching a single silica microsphere $(5 \mu \mathrm{m}$ of diameter, Bangs Laboratories) with a thin layer of UV-curable glue (NOA 63, Norland Edmund Optics). These colloidal probes were then put under UV-light for $10 \mathrm{~min}$ to allow the glue to cure. They were further dipped into a thin layer of UV-curable glue, then into a thin layer CNCS particles deposited on a glass slide. Functionalized cantilevers were then put under UV-light for $10 \mathrm{~min}$ to allow the glue to cure and further characterized using scanning electron microscopy (Figure S3). The spring constant of the colloidal probe was determined after attachment of the CNC particles using the thermal noise method. ${ }^{55}$

Functionalization with single $C$. vulgaris cells: AFM cantilevers were also functionalized with single $C$. vulgaris cells grown during 7 days in the conditions described previously. For that, cantilevers were first activated using oxygen plasma ( $3 \mathrm{~min}, 0.5 \mathrm{mbar}$ ) and then incubated in a $0.2 \%$ polyethylenimine solution (PEI, Sigma-Aldrich) overnight. The AFM cantilevers were then rinsed in PBS at a pH of 6 or 8 , brought into contact with an isolated cell and retracted to attach it. Proper attachment of the cell on the colloidal probe was checked using optical microscopy. The spring constant of the AFM cantilever was determined prior to cell immobilization using the thermal noise method. ${ }^{55}$

Functionalization with negatively charged beads: AFM cantilevers were functionalized using $\mathrm{COOH}$ polystyrene beads (negatively charged at pH 6 and 8, diameter of $6.83 \mu \mathrm{m}$, Spherotech, USA). Beads were first centrifuged ( $3 \mathrm{~min}, 13000 \mathrm{rpm}$ ) and washed two time in deionized water. A drop from this solution was then deposited on a glass slide and allowed to dry at $37^{\circ} \mathrm{C}$ during 2 hours. Cantilevers were first dipped into a thin layer of UV-curable glue (NOA 63, Norland Edmund Optics), and then brought into contact a single isolated bead on the glass slide and retracted to attach it. Functionalized cantilevers were then put under UV-light for $10 \mathrm{~min}$ to allow the glue to cure; proper 
attachment of the $\mathrm{COOH}$ bead on the colloidal probe was checked using optical microscopy. The spring constant of the $\mathrm{COOH}$ probe was determined after attachment of the $\mathrm{COOH}$ bead using the thermal noise method. ${ }^{55}$

Force spectroscopy experiments. Force spectroscopy experiments were conducted either by functionalizing the cantilever with CNCs and probing the interactions with immobilized cells on a surface (method 1), using FluidFM technology to aspirate a single $C$. vulgaris cell at the aperture of a microfluidic AFM probe to probe interactions with cationic CNCs functionalized on a surface (method 2), or by functionalizing the AFM cantilever with a single $C$. vulgaris cells and probing the interactions with chitosan immobilized on a surface (method 3). In each case, experiments were performed in PBS at a pH of 6 or 8 , using a NanoWizard III AFM (Bruker, USA). These 3 methods are also depicted in Figure S2.

Method 1: This method was used to probe the interactions between CNCS or negatively charged beads, and single C. vulgaris cells. In this case, CNCs (unmodified, PYR and MIM) or negatively charged beads functionalized cantilevers were directly used to probe the interactions with C. vulgaris cells immobilized on polyethylenimine (PEI Sigma P3143) coated glass slides prepared as previously described $^{56}$. For that, cells were first harvested by centrifugation ( $3000 \mathrm{rpm}, 3 \mathrm{~min}$ ) and washed two times in PBS at $\mathrm{pH} 6$ or 8 . Freshly oxygen activated glass slides were covered by a $0.2 \%$ PEl solution in deionized water and left for incubation overnight. Then the glass slides were rinsed with deionized water and dried under nitrogen. A total of $1 \mathrm{~mL}$ of the cell suspension was then deposited on the PEI slides, allowed to stand for 30 min at room temperature, and rinsed with PBS at pH 6 or 8 .

Method 2: This method was also used to probe the interactions between CNCs and single $C$. vulgaris cells. As the forces recorded between CNCs and cells were stronger that the electrostatic forces between PEI coated glass-slides and cells, this method was alternatively used to complete the data sets. In this case, FluidFM technology was used (Cytosurge AG, Switzerland): this system connects the AFM to a pressure pump unit and a pressure controller through a microfluidic tubing system. Micropipette probes with an aperture of $4 \mu \mathrm{m}$ (spring constant of $0.3 \mathrm{~N} / \mathrm{m}$ ) were used (Cytosurge AG, 

cantilever by applying an overpressure (100 mBar). The probe was then immersed in PBS and

663 calibrated using the thermal noise method prior to measurement. A single $C$. vulgaris cell was then picked up from the surface of the Petri dish by approaching the FluidFM probe and applying a negative pressure $(-80 \mathrm{mBar})$. The transfer of the cell on the probe was verified by optical microscopy. The cell probe was then used to probe the interactions with CNCs-functionalized mica surfaces. For that, CNCs solutions at a concentration of $5 \mathrm{~g} / \mathrm{L}$ were first sonicated for at least for 5 min, then deposited on mica surfaces and left for incubation overnight. After that the mica surfaces experiment.

671 Method 3: This method was used to probe the interactions between chitosan and single $C$. vulgaris 672 cells. In this case, AFM cantilevers functionalized with a single $C$. vulgaris cells were used to probe the 673 interactions with chitosan-functionalized surfaces, in PBS pH 6 or 8. Chitosan was functionalized at 674 the surface of glass-slide using spin-coating method, according to procedures described in ${ }^{42,43}$. 675 Briefly, $50 \mathrm{mg}$ of chitosan was first dissolved in $10 \mathrm{~mL}$ of deionized water containing 30-50 $\mu \mathrm{L}$ of hydrochloric acid $(\mathrm{HCl})$. This solution was then deposited on a clean glass slide and spin-coated at $6771000 \mathrm{rpm}$ for $3 \mathrm{~min}$. The glass slides were then dried in an incubator at $50^{\circ} \mathrm{C}$ overnight, before use.

678 Roughness analyses. Roughness analyses were performed on cells immobilized on PEl-coated glass 679 slides and on chitosan-functionalized glass slides. In both cases, images were recorded in PBS at pH 6 680 or 8 using contact mode on a Nanowizard III AFM (Bruker, USA), with MSCT cantilevers (Bruker, 681 nominal spring constant of $0.01 \mathrm{~N} / \mathrm{m}$ ). Images were recorded using an applied force of $<0.5 \mathrm{nN}$. The 682 cantilevers spring constants were determined by the thermal noise method. ${ }^{55}$

683 Nanomechanical analysis. For nanoindentation experiments, the applied force was comprised 684 between 0.5 and $2 \mathrm{nN}$ depending on the condition with MSCT cantilevers (Bruker, nominal spring 685 constant of $0.01 \mathrm{~N} / \mathrm{m}$ ). Young's moduli were then calculated from $80 \mathrm{~nm}$ indentation curves using the 686 Hertz mode $\left.\right|^{52}$ in which the force $F$, indentation $(\delta)$ and Young's modulus $(\mathrm{Ym})$ follow equation 2, 
689

690

691

692

693

694

695

696

697

698

699

700

701

702

703

704

705

706

707

where $\alpha$ is the tip opening angle $\left(17.5^{\circ}\right)$, and $u$ the Poisson ratio (arbitrarily assumed to be 0.5 ). The cantilevers spring constants were determined by the thermal noise method. ${ }^{55}$

$$
F=\frac{2 \times Y m \times \tan \alpha}{\pi \times\left(1-v^{2}\right) \times \delta^{2}}
$$

Scanning electron microscopy imaging of AFM cantilevers. AFM cantilevers functionalized or not with CNCs or chitosan were first carbonated and then imaged using a Jeol 6400 electron microscope (Jeol, Tokyo, Japan) equipped with an EDS Bruker SDD detector, at an acceleration voltage of 20kV.

\section{ACKNOWLEDGEMENTS}

C. F.-D. is a researcher at CNRS. C. F.-D. acknowledges financial support for this work from the Agence Nationale de la Recherche, JCJC project FLOTALG (ANR-18-CE43-0001-01). J. B., W. T. and K. M. acknowledge financial support for this work from Research Foundation Flanders (grant G.0608.16N) and from the EU Interreg France-Wallonie-Vlaanderen program through the ALPO project. W. T. further acknowledges the Provincie West-Vlaanderen for his Chair in Advance Materials, Research Foundation Flanders for his Odysseus fellowship (grant G.0C60.13N), and the European Union's European Fund for Regional Development, Flanders Innovation \& Entrepreneurship and the Province of West-Flanders for financial support in the Accelerate ${ }^{3}$ project (Interreg Vlaanderen-Nederland program). The authors would like to thank Prof. Dries Vandamme for his contribution in the flocculation experiments.

\section{SUPPORTING INFORMATION}

- Supplementary Table S1. Conductometric titration results

- Supplementary Table S2. Dynamic viscosity at different shear rates (1.0 1/s 10.0 1/s and 100.0 $1 / \mathrm{s})$

- Supplementary Table S3. Adhesion force values recorded between single $C$. vulgaris cells and CNCs/chitosan coated surfaces. 
- Supplementary Table S4. Adhesion force values and percentage of adhesions recorded between single $C$. vulgaris cells and chitosan coated surface at $\mathrm{pH} 6$ with increasing set point (applied force during approach).

- Supplementary Table S5. Adhesion force values and percentage of adhesions recorded between single $C$. vulgaris cells and chitosan coated surface at pH 8 with increasing set point (applied force during approach).

- Supplementary Table S6. Young's modulus values recorded on C. vulgaris cells at pH 6 and pH 8 . Values were calculated from $80 \mathrm{~nm}$ indentation curves using the Hertz model.

- Supplementary Figure S1. Conductometric titration curve of chitosan with DD $=77.5 \pm 0.8 \%$, titrated with $5.75 \mathrm{mM} \mathrm{NaOH}$. The replicas and chitosan samples provided by the Nha Trang University have similar results and were not shown.

- Supplementary Figure S2. Schematic representation of the three force spectroscopy methods used. a) CNCs (unmodified, PYR and MIM) or negatively charged beads functionalized cantilevers are used to probe the interactions with cells immobilized on polyethylenimine coated glass slides. b) A single $C$. vulgaris cell aspirated at the aperture of a FluidFM probe $(4 \mu \mathrm{m})$ are used to probe the interactions with CNCs-functionalized mica surfaces. c) AFM cantilevers functionalized with a single $C$. vulgaris cells are used to probe the interactions with chitosan-functionalized surfaces.

- Supplementary Figure S3. Scanning electron microscopy imaging of AFM cantilevers. a) AFM cantilever with a single silica bead attached b) AFM cantilever with a silica bead functionalized with an unmodified CNC particle c) AFM cantilever with a silica bead functionalized with a CNCMIM particle and d) AFM cantilever with a silica bead functionalized with a CNC-PYR particle.

- Supplementary Figure S4. Interactions between negative beads and CNC surfaces. a) Adhesion force histogram between a $\mathrm{COOH}$ bead-functionalized cantilever and CNC-PYR immobilized on mica at $\mathrm{pH} 8, \mathrm{~b}$ ) corresponding rupture distance histogram c) Adhesion force histogram between a $\mathrm{COOH}$ bead-functionalized cantilever and CNC-MIM at pH 8 d) corresponding rupture distance 

using a set-point of $0.25 \mathrm{nN}$.

\section{AUTHOR INFORMATION}

Corresponding author: Cécile Formosa-Dague, formosa@insa-toulouse.fr

Toulouse Biotechnology Institute, INSA de Toulouse, 135 avenue de Rangeuil, 31077 Toulouse Cedex

4, France

\section{AUTHOR CONTRIBUTIONS}

The manuscript was written through contributions of all authors. All authors have given approval to

the final version of the manuscript. $¥$ I. D. and J. B. contributed equally to the work.

\section{REFERENCES}

(1) Pragya, N.; Pandey, K. K.; Sahoo, P. K. A Review on Harvesting, Oil Extraction and Biofuels Production Technologies from Microalgae. Renewable and Sustainable Energy Reviews 2013,

24, 159-171. https://doi.org/10.1016/j.rser.2013.03.034.

(2) Algae Bloom Again. Nature 2007, 447 (7144), 520-521. https://doi.org/10.1038/447520a.

(3) Wijffels, R. H.; Barbosa, M. J. An Outlook on Microalgal Biofuels. Science 2010, 329 (5993), 796-799. https://doi.org/10.1126/science.1189003.

(4) Mallick, N.; Mandal, S.; Singh, A. K.; Bishai, M.; Dash, A. Green Microalga Chlorella Vulgaris as a Potential Feedstock for Biodiesel. Journal of Chemical Technology \& Biotechnology 2012, 87 (1), 137-145. https://doi.org/10.1002/jctb.2694.

(5) Ziolkowska, J. R. Prospective Technologies, Feedstocks and Market Innovations for Ethanol and Biodiesel Production in the US. Biotechnology Reports 2014, 4, 94-98. https://doi.org/10.1016/j.btre.2014.09.001.

(6) Beijerinck, M. W. I. Kulturversuche Mit Zoochlorellen, Lichenengonidien Und Anderen Niederen Algen. Botanische Zeitung 1890, 48, 729.

(7) Safi, C.; Zebib, B.; Merah, O.; Pontalier, P.-Y.; Vaca-Garcia, C. Morphology, Composition, Production, Processing and Applications of Chlorella Vulgaris: A Review. Renewable and Sustainable Energy Reviews 2014, 35, 265-278. https://doi.org/10.1016/j.rser.2014.04.007.

(8) Morimoto, T.; Nagatsu, A.; Murakami, N.; Sakakibara, J.; Tokuda, H.; Nishino, H.; Iwashima, A. Anti-Tumour-Promoting Glyceroglycolipids from the Green Alga, Chlorella Vulgaris. Phytochemistry 1995, 40 (5), 1433-1437. https://doi.org/10.1016/0031-9422(95)00458-J.

(9) Justo, G. Z.; Silva, M. R.; Queiroz, M. L. S. Effects of the Green Algae Chlorella Vulgaris on the Response of the Host Hematopoietic System to Intraperitoneal Ehrlich Ascites Tumor Transplantation in Mice. Immunopharmacology and Immunotoxicology 2001, 23 (1), 119-132. https://doi.org/10.1081/IPH-100102573. 
(10) Shen, X.-F.; Liu, J.-J.; Chauhan, A. S.; Hu, H.; Ma, L.-L.; Lam, P. K. S.; Zeng, R. J. Combining Nitrogen Starvation with Sufficient Phosphorus Supply for Enhanced Biodiesel Productivity of Chlorella Vulgaris Fed on Acetate. Algal Research 2016, 17, 261-267. https://doi.org/10.1016/j.algal.2016.05.018.

(11) Shen, X.-F.; Qin, Q.-W.; Yan, S.-K.; Huang, J.-L.; Liu, K.; Zhou, S.-B. Biodiesel Production from Chlorella Vulgaris under Nitrogen Starvation in Autotrophic, Heterotrophic, and Mixotrophic Cultures. J Appl Phycol 2019, 31 (3), 1589-1596. https://doi.org/10.1007/s10811-019-017651.

(12) Molina Grima, E.; Belarbi, E.-H.; Acién Fernández, F. G.; Robles Medina, A.; Chisti, Y. Recovery of Microalgal Biomass and Metabolites: Process Options and Economics. Biotechnology Advances 2003, 20 (7), 491-515. https://doi.org/10.1016/S0734-9750(02)00050-2.

(13) Singh, G.; Patidar, S. K. Microalgae Harvesting Techniques: A Review. Journal of Environmental Management 2018, 217, 499-508. https://doi.org/10.1016/j.jenvman.2018.04.010.

(14) Lardon, L.; Hélias, A.; Sialve, B.; Steyer, J.-P.; Bernard, O. Life-Cycle Assessment of Biodiesel Production from Microalgae. Environ. Sci. Technol. 2009, 43 (17), 6475-6481. https://doi.org/10.1021/es900705j.

(15) Shimako, A. H.; Tiruta-Barna, L.; Pigné, Y.; Benetto, E.; Navarrete Gutiérrez, T.; Guiraud, P.; Ahmadi, A. Environmental Assessment of Bioenergy Production from Microalgae Based Systems. Journal of Cleaner Production 2016, 139, 51-60. https://doi.org/10.1016/j.jclepro.2016.08.003.

(16) Kadir, W. N. A.; Lam, M. K.; Uemura, Y.; Lim, J. W.; Lee, K. T. Harvesting and Pre-Treatment of Microalgae Cultivated in Wastewater for Biodiesel Production: A Review. Energy Conversion and Management 2018, 171, 1416-1429. https://doi.org/10.1016/j.enconman.2018.06.074.

(17) Vandamme, D.; Foubert, I.; Muylaert, K. Flocculation as a Low-Cost Method for Harvesting Microalgae for Bulk Biomass Production. Trends in Biotechnology 2013, 31 (4), 233-239. https://doi.org/10.1016/j.tibtech.2012.12.005.

(18) Vandamme, D.; Foubert, I.; Muylaert, K. Flocculation as a Low-Cost Method for Harvesting Microalgae for Bulk Biomass Production. Trends in Biotechnology 2013, 31 (4), 233-239. https://doi.org/10.1016/j.tibtech.2012.12.005.

(19) Pugazhendhi, A.; Shobana, S.; Bakonyi, P.; Nemestóthy, N.; Xia, A.; Banu J, R.; Kumar, G. A Review on Chemical Mechanism of Microalgae Flocculation via Polymers. Biotechnology Reports 2019, 21, e00302. https://doi.org/10.1016/j.btre.2018.e00302.

(20) Renault, F.; Sancey, B.; Badot, P.-M.; Crini, G. Chitosan for Coagulation/Flocculation Processes - An Eco-Friendly Approach. European Polymer Journal 2009, 45 (5), 1337-1348. https://doi.org/10.1016/j.eurpolymj.2008.12.027.

(21) Chen, G.; Zhao, L.; Qi, Y.; Cui, Y.-L. Chitosan and Its Derivatives Applied in Harvesting Microalgae for Biodiesel Production: An Outlook https://www.hindawi.com/journals/jnm/2014/217537/ (accessed Feb 3, 2020). https://doi.org/10.1155/2014/217537.

(22) Ahmad, A. L.; Mat Yasin, N. H.; Derek, C. J. C.; Lim, J. K. Optimization of Microalgae Coagulation Process Using Chitosan. Chemical Engineering Journal 2011, 173 (3), 879-882. https://doi.org/10.1016/j.cej.2011.07.070.

(23) Ritthidej, G. C. Chapter 3 - Nasal Delivery of Peptides and Proteins with Chitosan and Related Mucoadhesive Polymers. In Peptide and Protein Delivery; Van Der Walle, C., Ed.; Academic Press: Boston, 2011; pp 47-68. https://doi.org/10.1016/B978-0-12-384935-9.10003-3.

(24) Bilanovic, D.; Shelef, G.; Sukenik, A. Flocculation of Microalgae with Cationic Polymers Effects of Medium Salinity. Biomass 1988, 17 (1), 65-76. https://doi.org/10.1016/01444565(88)90071-6.

(25) Rashid, N.; Rehman, S. U.; Han, J.-I. Rapid Harvesting of Freshwater Microalgae Using Chitosan. Process Biochemistry 2013, 48 (7), 1107-1110. https://doi.org/10.1016/j.procbio.2013.04.018. 
(26) Low, Y. J.; Lau, S. W. Effective Flocculation of Chlorella Vulgaris Using Chitosan with Zeta Potential Measurement. IOP Conf. Ser.: Mater. Sci. Eng. 2017, 206, 012073. https://doi.org/10.1088/1757-899X/206/1/012073.

(27) Matho, C.; Schwarzenberger, K.; Eckert, K.; Keshavarzi, B.; Walther, T.; Steingroewer, J.; Krujatz, F. Bio-Compatible Flotation of Chlorella Vulgaris: Study of Zeta Potential and Flotation Efficiency. Algal Research 2019, 44, 101705. https://doi.org/10.1016/j.algal.2019.101705.

(28) Garzon-Sanabria, A. J.; Ramirez-Caballero, S. S.; Moss, F. E. P.; Nikolov, Z. L. Effect of Algogenic Organic Matter (AOM) and Sodium Chloride on Nannochloropsis Salina Flocculation Efficiency. Bioresource Technology 2013, 143, 231-237. https://doi.org/10.1016/j.biortech.2013.05.125.

(29) Farid, M. S.; Shariati, A.; Badakhshan, A.; Anvaripour, B. Using Nano-Chitosan for Harvesting Microalga Nannochloropsis Sp. Bioresource Technology 2013, 131, 555-559. https://doi.org/10.1016/j.biortech.2013.01.058.

(30) Faridi, M. A.; Ramachandraiah, H.; Banerjee, I.; Ardabili, S.; Zelenin, S.; Russom, A. ElastoInertial Microfluidics for Bacteria Separation from Whole Blood for Sepsis Diagnostics. Journal of Nanobiotechnology 2017, 15 (1). https://doi.org/10.1186/s12951-016-0235-4.

(31) Blockx, J.; Verfaillie, A.; Thielemans, W.; Muylaert, K. Unravelling the Mechanism of ChitosanDriven Flocculation of Microalgae in Seawater as a Function of PH. ACS Sustainable Chem. Eng. 2018, 6 (9), 11273-11279. https://doi.org/10.1021/acssuschemeng.7b04802.

(32) Cheng, Y.-S.; Zheng, Y.; Labavitch, J. M.; VanderGheynst, J. S. The Impact of Cell Wall Carbohydrate Composition on the Chitosan Flocculation of Chlorella. Process Biochemistry 2011, 46 (10), 1927-1933. https://doi.org/10.1016/j.procbio.2011.06.021.

(33) Binnig, G.; Quate, C. F.; Gerber, C. Atomic Force Microscope. Physical Review Letters 1986, 56 (9), 930-934.

(34) Formosa-Dague, C.; Gernigon, V.; Castelain, M.; Daboussi, F.; Guiraud, P. Towards a Better Understanding of the Flocculation/Flotation Mechanism of the Marine Microalgae Phaeodactylum Tricornutum under Increased PH Using Atomic Force Microscopy. Algal Research 2018, 33, 369-378. https://doi.org/10.1016/j.algal.2018.06.010.

(35) Besson, A.; Formosa-Dague, C.; Guiraud, P. Flocculation-Flotation Harvesting Mechanism of Dunaliella Salina: From Nanoscale Interpretation to Industrial Optimization. Water Research 2019, 155, 352-361. https://doi.org/10.1016/j.watres.2019.02.043.

(36) Vergnes, J. B.; Gernigon, V.; Guiraud, P.; Formosa-Dague, C. Bicarbonate Concentration Induces Production of Exopolysaccharides by Arthrospira Platensis That Mediate Bioflocculation and Enhance Flotation Harvesting Efficiency. ACS Sustainable Chem. Eng. 2019, 7 (16), 13796-13804. https://doi.org/10.1021/acssuschemeng.9b01591.

(37) Blockx, J.; Verfaillie, A.; Eyley, S.; Deschaume, O.; Bartic, C.; Muylaert, K.; Thielemans, W. Cationic Cellulose Nanocrystals for Flocculation of Microalgae: Effect of Degree of Substitution and Crystallinity. ACS Appl. Nano Mater. 2019, 2 (6), 3394-3403. https://doi.org/10.1021/acsanm.9b00315.

(38) Chen, L.; Chen, D.; Wu, C. A New Approach for the Flocculation Mechanism of Chitosan. Journal of Polymers and the Environment 2003, 11 (3), 87-92. https://doi.org/10.1023/A:1024656813244.

(39) Demir, I.; Besson, A.; Guiraud, P.; Formosa-Dague, C. Towards a Better Understanding of Microalgae Natural Flocculation Mechanisms to Enhance Flotation Harvesting Efficiency. Water Sci Technol 2020. https://doi.org/10.2166/wst.2020.177.

(40) Verfaillie, A.; Blockx, J.; Praveenkumar, R.; Thielemans, W.; Muylaert, K. Harvesting of Marine Microalgae Using Cationic Cellulose Nanocrystals. Carbohydrate Polymers 2020, 240, 116165. https://doi.org/10.1016/j.carbpol.2020.116165.

(41) Alsteens, D.; Beaussart, A.; Derclaye, S.; El-Kirat-Chatel, S.; Park, H. R.; Lipke, P. N.; Dufrêne, Y. F. Single-Cell Force Spectroscopy of Als-Mediated Fungal Adhesion. Anal. Methods 2013, 5 (15), 3657-3662. https://doi.org/10.1039/C3AY40473K. 
(42) Yao, H.-B.; Fang, H.-Y.; Tan, Z.-H.; Wu, L.-H.; Yu, S.-H. Biologically Inspired, Strong, Transparent, and Functional Layered Organic-Inorganic Hybrid Films. Angewandte Chemie International Edition 2010, 49 (12), 2140-2145. https://doi.org/10.1002/anie.200906920.

(43) Carapeto, A. P.; Ferraria, A. M.; Rego, A. M. B. do. Chitosan Thin Films on Glass and Silicon Substrates. Microscopy and Microanalysis 2015, 21 (S5), 13-14. https://doi.org/10.1017/S1431927615013872.

(44) Formosa, C.; Grare, M.; Jauvert, E.; Coutable, A.; Regnouf-de-Vains, J. B.; Mourer, M.; Duval, R. E.; Dague, E. Nanoscale Analysis of the Effects of Antibiotics and CX1 on a Pseudomonas Aeruginosa Multidrug-Resistant Strain. Sci. Rep. 2012, 2. https://doi.org/10.1038/srep00575.

(45) Formosa-Dague, C.; Speziale, P.; Foster, T. J.; Geoghegan, J. A.; Dufrêne, Y. F. Zinc-Dependent Mechanical Properties of Staphylococcus Aureus Biofilm-Forming Surface Protein SasG. PNAS 2016, 113 (2), 410-415. https://doi.org/10.1073/pnas.1519265113.

(46) Formosa-Dague, C.; Feuillie, C.; Beaussart, A.; Derclaye, S.; Kucharíková, S.; Lasa, I.; Van Dijck, P.; Dufrêne, Y. F. Sticky Matrix: Adhesion Mechanism of the Staphylococcal Polysaccharide Intercellular Adhesin. ACS Nano 2016, 10 (3), 3443-3452. https://doi.org/10.1021/acsnano.5b07515.

(47) Higgins, M. J.; Molino, P.; Mulvaney, P.; Wetherbee, R. The Structure and Nanomechanical Properties of the Adhesive Mucilage That Mediates Diatom-Substratum Adhesion and Motility1. Journal of Phycology 2003, 39 (6), 1181-1193. https://doi.org/10.1111/j.00223646.2003.03-027.x.

(48) Myllytie, P.; Salmi, J.; Laine, J. THE INFLUENCE OF PH ON THE ADSORPTION AND INTERACTION OF CHITOSAN WITH CELLULOSE. BioResources 2009, 4 (4), 1647-1662.

(49) Simsek-Ege, F. A.; Bond, G. M.; Stringer, J. Polyelectrolyte Complex Formation between Alginate and Chitosan as a Function of PH. Journal of Applied Polymer Science 2003, 88 (2), 346-351. https://doi.org/10.1002/app.11989.

(50) Barany, S.; Szepesszentgyörgyi, A. Flocculation of Cellular Suspensions by Polyelectrolytes. Advances in Colloid and Interface Science 2004, 111 (1), 117-129. https://doi.org/10.1016/j.cis.2004.07.003.

(51) Boonsongrit, Y.; Mitrevej, A.; Mueller, B. W. Chitosan Drug Binding by Ionic Interaction. European Journal of Pharmaceutics and Biopharmaceutics 2006, 62 (3), 267-274. https://doi.org/10.1016/j.ejpb.2005.09.002.

(52) Hertz, H. Ueber Die Beruhrung Fester Elastischer Korper. Journal fur die reine und angewandte mathematik 1881, 156-171.

(53) Formosa, C.; Schiavone, M.; Martin-Yken, H.; François, J. M.; Duval, R. E.; Dague, E. Nanoscale Effects of Caspofungin against Two Yeast Species, Saccharomyces Cerevisiae and Candida Albicans. Antimicrob. Agents Chemother. 2013, 57 (8), 3498-3506. https://doi.org/10.1128/AAC.00105-13.

(54) Guillard, R. R. L.; Lorenzen, C. J. Yellow-Green Algae with Chlorophyllide C2. Journal of Phycology 1972, 8 (1), 10-14.

(55) Hutter, J. L.; Bechhoefer, J. Calibration of Atomic-Force Microscope Tips. Review of Scientific Instruments 1993, 64 (7), 1868-1873.

(56) Francius, G.; Tesson, B.; Dague, E.; Martin-Jézéquel, V.; Dufrêne, Y. F. Nanostructure and Nanomechanics of Live Phaeodactylum Tricornutum Morphotypes. Environ. Microbiol. 2008, 10 (5), 1344-1356. https://doi.org/10.1111/j.1462-2920.2007.01551.x. 